IZA DP No. 6148

Rubble Women: The Long-Term Effects of Postwar Reconstruction on Female Labor Market Outcomes

Mevlude Akbulut-Yuksel

Melanie Khamis

Mutlu Yuksel

November 2011 


\title{
Rubble Women: \\ The Long-Term Effects of Postwar Reconstruction on Female Labor Market Outcomes
}

\author{
Mevlude Akbulut-Yuksel \\ Dalhousie University, HICN and IZA \\ Melanie Khamis \\ Wesleyan University and IZA \\ Mutlu Yuksel \\ Dalhousie University and IZA
}

Discussion Paper No. 6148

November 2011

\author{
IZA \\ P.O. Box 7240 \\ 53072 Bonn \\ Germany
}

Phone: +49-228-3894-0

Fax: +49-228-3894-180

E-mail: iza@iza.org

\begin{abstract}
Any opinions expressed here are those of the author(s) and not those of IZA. Research published in this series may include views on policy, but the institute itself takes no institutional policy positions.

The Institute for the Study of Labor (IZA) in Bonn is a local and virtual international research center and a place of communication between science, politics and business. IZA is an independent nonprofit organization supported by Deutsche Post Foundation. The center is associated with the University of Bonn and offers a stimulating research environment through its international network, workshops and conferences, data service, project support, research visits and doctoral program. IZA engages in (i) original and internationally competitive research in all fields of labor economics, (ii) development of policy concepts, and (iii) dissemination of research results and concepts to the interested public.
\end{abstract}

IZA Discussion Papers often represent preliminary work and are circulated to encourage discussion. Citation of such a paper should account for its provisional character. A revised version may be available directly from the author. 
IZA Discussion Paper No. 6148

November 2011

\title{
ABSTRACT \\ Rubble Women: The Long-Term Effects of Postwar Reconstruction on Female Labor Market Outcomes
}

\begin{abstract}
During World War II, more than one-half million tons of bombs were dropped in aerial raids on German cities, destroying about forty percent of the total housing stock nationwide. With a large fraction of the male population gone, the reconstruction process had mainly fallen on women in postwar Germany. This paper provides causal evidence on long-term legacies of postwar reconstruction and mandatory employment on women's labor market outcomes. We combine a unique dataset on city-level destruction in Germany caused by the Allied Air Forces bombing during WWII with individual survey data from the German Microcensus. Using difference-in-difference and instrumental-variable strategies, we find that postwar mandatory employment reduced female labor force participation and hours worked in the long-run. However, our results show that participating in postwar reconstruction efforts increased the female presence in medium-skill and female-dominated occupations. These results survive after accounting for labor supply side factors such as wealth and savings loss during WWII, war relief payments and change in the composition of population and labor demand side factors such as female share in industry, construction, service and public sectors.
\end{abstract}

JEL Classification: $\quad$ I21, I12, J24, N34

Keywords: postwar reconstruction, female labor force participation, occupational choice

Corresponding author:

Mevlude Akbulut-Yuksel

Department of Economics

Dalhousie University

6214 University Avenue

Halifax, NS, B3H $3 J 5$

Canada

E-mail: mevlude@dal.ca

\footnotetext{
* We are grateful to Aimee Chin, Gordon Dahl, Amanda Goodall, Joyce Jacobsen, Chinhui Juhn, Adriana Kugler, Peter Kuhn, Andrew Oswald, Shelley Phipps, Olga Shemyakina and Courtney Ward as well as seminar participants at Wesleyan University, Dalhousie University and IZA for their helpful comments and suggestions. We thank the Research Data Center (RDC) of the Federal Statistical Office of Germany and the Statistical Offices of the Laender for access to the Mikrocensus data and in particular Rafael Czaja for continued support. Parts of this paper were prepared during our stay at the Institute for the Study of Labor (IZA). We thank IZA for providing financial support and a stimulating research environment. We also thank Margard Ody and Georgios Tassoukis for their help with the data and historical records. The authors bare the sole responsibility for any errors that may remain.
} 


\section{Introduction}

Large and aggregate shocks caused by natural disasters and armed conflicts have devastating consequences for a country, including loss of lives, displacement of people, destruction of physical capital and public infrastructure, and reduced economic growth. Evidence from macro-level studies predicts rapid recovery after these large physical shocks such that city population, physical infrastructure, literacy and poverty levels return to their steady state within 20-25 years (Miguel and Roland, 2006; Brakman, Garretsen and Schramm, 2004; Davis and Weinstein, 2002). However, natural disasters and armed conflicts still inflict direct and external long-term costs on survivors which can last longer and be as detrimental as physical impacts. ${ }^{2}$

This paper provides causal evidence on long-term legacies of postwar reconstruction and mandatory employment on women's labor market outcomes. Specifically, we use city-by-cohort variation in destruction in Germany arising from the Allied Air Forces (hereafter, "AAF") bombing throughout World War II as a unique quasi-experiment. During WWII, more than one and a half million tons of bombs were dropped in aerial raids on German cities, destroying about 40 percent of the nationwide total housing stock (Diefendorf, 1993). Germany also lost a substantial fraction of its male population during WWII, due to war deaths and being captured as prisoners of war. Thus, the removal of rubble and postwar reconstruction had mainly fallen on women (Heineman, 1996; Meiners, 2011). To increase the participation in the rubble removal and reconstruction efforts, the Allied Control Council announced Command Nr. 3 in January 1946, which remained in place until February 1955 in West Germany. ${ }^{3}$ This law required all individuals capable of work (men between 14 and 65 and women between 15 and 50 years of age) to register with labor offices (Allied Control Authority Germany, 1946) for work allocation.

\footnotetext{
${ }^{2}$ For detailed information on armed conflicts, see Blattman and Miguel (2010).

${ }^{3}$ Command Nr. 3 was extended as Law Nr.32 in February 1946.
} 
If a person did not register and obtain the certificate of registration, the penalty was to lose their right to receive food ration cards. With the passage of mandatory employment law, therefore so called "rubble women" (in German Truemmerfrauen) entered into the labor force and started to work in professions such as construction and industry which were previously closed to them.

The postwar mobilization of rubble women was mainly determined by the extent of wartime destruction experienced in their city of residence. In cities with higher wartime destruction, women were required to work for longer time period and more intensively in the rubble removal and reconstruction compared to women residing in less destructed areas. On the other hand, only women who were within the mandatory working age during reconstruction period would have had their labor market outcomes affected by the postwar mandatory employment law; the labor market outcomes of women who entered the labor market after the reconstruction period was completed in late 1950s would not have been impacted by this law. This paper therefore uses a difference-in-differences-type strategy where the "treatment" variable is an interaction between city-level wartime destruction and a dummy variable for being of working-age during the reconstruction period, and where we always control for city fixed effects and birth year fixed effects. The identifying assumption is that had the postwar mandatory employment not occurred, the difference in women's labor market outcomes between the affected cohorts and cohorts that entered the labor market after the reconstruction period would have been the same across cities with varying intensity of destruction.

In addition, as robustness to the difference-in-difference analysis, we use an alternative estimation strategy and instrument the city-level war destruction with distance to London where AAF airfields were mainly located. Due to their proximity to the U.K., cities in the northern and western parts of Germany suffered the most from the AAF aerial bombing during WWII. 
Distance from London, however could capture a wide range of factors including economic advantage and might affect women's labor market outcomes through channels other than WWII destruction. We assess the validity of the instrument in Section 5 by comparing cities' prewar characteristics by distance to London and find no variation across cities.

Our paper is most closely related to Acemoglu, Author and Lyle (2004) and Goldin (1991) who analyze the effects of WWII mobilization in the US on female labor supply in 1950. Acemoglu, Author and Lyle (2004) find that mobilization of men during WWII increased female labor force participation in 1950, which lowered both female and male wages. Goldin (1991), however, draws a different conclusion on the effects of WWII on female labor force participation. She finds that a modest effect of WWII on employment of women in 1950 where the majority of women who entered the labor market during the war years exited by 1950. Taken together, these studies focus on the short-term effects of WWII mobilization on women's employment and wages; however long-term effects of postwar employment may be quite different than short-term mobilization effects. On the one hand, the postwar employment of women in traditionally male-dominated occupations may have provided them an opportunity to acquire skills and knowledge that are rewarded in the labor market. Moreover, pervasive female employment in the postwar era might have altered the perceptions and preferences of women and encouraged them to continue working in the future. On the other hand, challenging working conditions and demanding manual labor during reconstruction may have led to a mental and physical exhaustion and long-term health problems discouraging these women from participating in the workforce in the long-run. Therefore, it is of interest to analyze the long-term impacts of postwar employment on female labor market outcomes. 
This study also contributes to a growing literature on the legacies of armed conflicts. Shemyakina (2011) and Menon and van der Meulen Rodgers (2011) examine women's employment in Tajikistan and Nepal during and just after the armed conflict, respectively. Shemyakina (2011) finds that young women residing in conflict regions in Tajikistan are more likely to be employed in the last 14 days compared to women in non-conflict regions. Menon and van der Meulen Rodgers (2011) provide similar evidence suggesting that exposure to conflict increased employment and self-employment among married women in Nepal. In contrast to these studies, however, in this study, we quantify the long-term effects of postwar mandatory employment on women's labor market outcomes. Our analysis combines a unique dataset on the extent of WWII destruction for each German Regional Policy Region (Raumordnungsregionen, hereafter, "ROR", "region" or "city") ${ }^{4}$ with individual-level data from the German Microcensus. We have collected very detailed data on rubble per capita and bombing intensity from historical and military archives for each German city, enabling us to quantify the realized wartime destruction. In contrast, other studies use a measure of exposure to war that has limited spatial variation and they have limited information on the intensity of exposure to war. Having measures of exposure to war at a lower level of aggregation enables us to more accurately match the treatment to each individual and form more plausible control groups. ${ }^{5}$ Second, we compiled unique data on postwar female/male ratio, share of females in industry, construction, service and public sectors, the amount of savings loss during WWII and per capita war relief payments, which enable us to rigorously investigate the potential labor supply and labor demand factors through which postwar mandatory employment affected the long-term labor market outcomes of

\footnotetext{
${ }^{4}$ The analysis is restricted to former West Germany. Former West Germany was comprised of 38 German Regional Policy Region (Raumordnungsregionen, hereafter, "ROR" or "city") in 1978.

${ }^{5}$ It is worth noting that Miguel and Roland (2006) measure bombing intensity in Vietnam at the district level, which is even, a lower level of aggregation than we use here. However, their analysis is not at the individual level (it is at the district level)
} 
women. Third, this paper may shed light on potential long-term impacts of work-contingent income support programs on female labor market outcomes. Over the past two decades, most of the developed countries have adopted large-scale work-contingent income support programs to increase the labor market participation of low-income households. A large empirical literature evaluated the impact of changes in Earned Income Tax Credit (EITC) in the US on the employment of single mothers and find that EITC increases employment. ${ }^{6}$ Due to data limitations, however, there are only a handful of studies that provides causal evidence on the impacts of these programs on women's long-term labor market outcomes and welfare participation (Card and Hyslop, 2005). Postwar mandatory employment therefore provides a unique opportunity to estimate the long-term effects of work-contingent income programs on labor market outcomes and welfare dependency of women.

We find that postwar mandatory employment had detrimental effects on women's longterm labor market outcomes. First, rubble women who were residing in a city with average WWII destruction have on average 4 percentage points lower probability to work full-time or work in general in the future. Second, challenging working conditions and hard labor during the reconstruction period led these women to work 2.1 fewer hours per week after the postwar mandatory employment was abolished. Finally, exposure to higher wartime reconstruction increased rubble women's presence in medium-skill and female-dominated occupations in the long-run. These results survive after we account for supply side factors such as wealth and savings loss during WWII, per capita war relief payments and refugee and migrant shares and demand side factors such as female share in industry, construction, service and public sectors. A

\footnotetext{
${ }^{6}$ See, Eissa and Liebman, 1996; Eissa and Hoynes, 1998, 2004; Meyer and Rosenbaum, 2000; Hotz, Mullin, and Scholz, 2006.
} 
mental and physical exhaustion from working in challenging conditions and increase in marriage and fertility rates after reconstruction period are potential mechanisms explaining our results.

The remainder of the paper is organized as follows. Section 2 provides a brief background of AAF bombing in Germany during WWII. Section 3 discusses the identification strategy. Section 4 describes the city-level destruction data and individual-level survey data used in the analysis. Section 5 presents the main results, extensions and robustness checks. Section 6 concludes.

\section{Background on WWII Destruction and Rubble Women}

During WWII, German cities experienced widespread bombardment of the AAF. The raids left more than 14 million people homeless (Heineman, 1996). Approximately 3.6 million civilians and 3.3 million soldiers had died and 11 million soldiers were captured as prisoners of war (Meiners, 2011). ${ }^{7}$ An overwhelming majority of the AAF's aerial attacks consisted of night time "area bombing" rather than "precision bombing". The aim of area bombing was to start a fire in the center of the each town, which would consume the whole town (USSBS, 1945).

During area bombings, AAF went on to attack almost every major and minor German city, though the number of bombs dropped and the intensity of destruction varied substantially across cities (the shaded area in Figure 1 shows the share of dwellings destroyed in German cities by the end of WWII). It is evident from Figure 1 that the targeted cities were selected not only because they were particularly important for the war effort, but also for their visibility from the air, depending for example on weather conditions or visibility of outstanding landmarks such as cathedrals (Friedrich, 2002). Furthermore, those cities most easily reached from the air fields

\footnotetext{
${ }^{7}$ The prisoners of war that were imprisoned by the Allied Forces were released by 1948. Additionally, by the early 1950s, most of the prisoners of war in Soviet camps were released as well (Meiners 2011, p. 124).
} 
in England in northern and western parts of Germany suffered the most destruction. For example, Berlin, which was nearly twice as far away as the cities in the Ruhr Area, was not hit as hard until the end of 1943 because of its great distance from British bomber airfields (Diefendorf, 1993; Grayling, 2006).

With large fraction of the male population gone, due to war deaths and being captured as prisoners of war, the reconstruction process and removal of rubble and postwar reconstruction had mainly fallen on women (Heineman, 1996; Meiners, 2011). In postwar Germany, these so called "rubble women" (in German Truemmerfrauen) entered into the labor force and worked in professions such as building works and construction which previously were closed to them. Before the World War II, women were restricted to certain professions such as teaching or working in agriculture. In Nazi Germany, women were seen as mothers and housewives and having children was one of their primary duties. During this time, women benefited from generous family allowances to give up their work (Heineman, 1996).

To increase the participation in the rubble removal and reconstruction among the German population, the Allied Control Council announced Command Nr. 3 on $17^{\text {th }}$ January 1946 (Allied Control Authority Germany 1946; Zentralamt fuer Arbeit 1947). This command required all individuals capable of work (for men between 14 and 65 and for women between 15 and 50 years of age) to register with labor offices for work allocation. If a person did not register and did not obtain the certificate of registration, the penalty was to lose the right to receive food ration cards. The work placements were made through the Labor offices which had the power to place people compulsory. Imprisonment and criminal prosecution was to follow if the employer did not comply with the command. In July 1946, Allied Control Council legalized Command Nr. 3 as Law Nr. 32 which formally allowed female employment in construction works and postwar 
reconstruction effort. Law Nr.32 remained in place from July 1946 to February 1955 for West Germany.

The historical debate on the role of women in postwar Germany is divided. On the one hand, several historians argue that the immediate postwar period can be seen as "Hour Zero" ("Stunde Null") of the German female emancipation movement (Hoehn, 1997). From this point onwards, Germany witnessed a further emancipation of women and this was seen as the key turning point in history. This strand of studies argues that there was a sustained increased in female labor supply, in particular part-time employment and increase in the divorce rates partly due to the returning male population not being able to deal with the changed circumstances (Hoehn, 1997, p.78). Women and their work contribution are seen as an important part of the German economic miracle (Hoehn, 1997, p.85). This view seems also consistent with the continued female labor force participation discussed as anecdotal evidence from rubble women themselves (Unruh, 1987; Jenk, 1988; Meiners, 2011).

On the other hand, however, a second strand of historians argues that the rubble women returned back to their kitchens and became housewives again (Heineman, 1996; Donath, 2008; Meiners, 2011). They argue that with the return of the prisoners of war in late 1940s, the German government and employees enacted laws and notions which aimed to reestablish the prewar social stability among the male-female population in the society and within the household. One of these notions was the "latchkey kid" ("Schluesselkind"), which was a term employed for children whose mother was working and who had to come home alone with their own key. Meiners (2011) discusses the question and puzzle of why women did not use their historic opportunity during Hour Zero to gain emancipation and sustain their standing in the world of work or political life in Germany. One of the explanations she puts forward was the sheer 
exhaustion and loss of energy due to the reconstruction period. This energy was used for the survival of women themselves and their children instead. This survival work led to mental and physical exhaustion (Moeding, 1988, p. 620). Very few women engaged in public affairs or in politics (Moeding, 1988, p. 623). Also the traditional gender role and the expectations that came with this, which were set over generations, were too engrained to make a change possible. Another potential reason could be the male shortages and the female belief that without a man they would have no standing in society (Meiners 2011, p.11). The non-participation of German women and mothers in the labor market is a concern even in 2011 (New York Times, 2011). The New York Times argues that historical factors such as the role of women during the Nazi-times as mothers and also in the $19^{\text {th }}$ century Social Democrat movement which attempted to protect women from the harsh work life are to be accounted for this current situation. Taken together, the question and puzzle of female emancipation in postwar Germany still remains to the day and requires scrutiny. To the best of our knowledge, the present paper is the first to attempt to understand the long-run impacts of postwar mandatory employment on female labor market outcomes in Germany.

\section{Identification Strategy}

In this section, we describe our strategy for identifying the long-term causal effect of postwar reconstruction on labor market outcomes of German women. This strategy exploits the plausibly exogenous city-by-cohort variation in destruction intensity. This is a difference-indifferences-type strategy where the "treatment" variable is an interaction between city-level intensity of WWII destruction and a dummy for being of working-age during the implementation 
of Allied Control Council's Command Nr. 3 and Law Nr. 32. ${ }^{8}$ In particular, the proposed estimate of the average treatment effect is given by $\beta$ in the following baseline city and year of birth fixed effects equation:

$$
\mathrm{Y}_{\text {irt }}=\alpha+\beta\left(\text { Destruction }_{r} \times \text { Rubble_Women }_{i t}\right)+\delta_{r}+\gamma_{t}+\pi^{\prime} \mathbf{X}_{\text {irt }}+\varepsilon_{i r t}
$$

where $\mathrm{Y}_{\text {irt }}$ is the outcome of interest for female $i$, in city $r$, born in year $t$. Destruction $r$ is the measure of war damage in the city $r$.Rubble_Women ${ }_{i t}$ is a dummy variable that takes a value of 1 if female $i$ was born between 1920 and 1934 and zero otherwise. Individuals born between 1920 and 1934 were 21 and older when the mandatory labor law was abolished in 1955; therefore, their labor market outcomes have the potential to be affected by postwar mandatory employment.

The labor market outcomes of women who enter the labor market after the reconstruction period was completed in the late 1950s would not have been impacted by this destruction; hence later birth cohorts are in the control group. As we explain below, we will use individuals born 1940-1954 as the control cohorts. $\delta_{r}$ is city-specific fixed effects, controlling for the fact that cities may be systematically different from each other. $\gamma_{t}$ is the year of birth fixed effects, controlling for common shocks experienced by women that were born during the same year. ${ }^{9} \mathbf{X}_{i r t}$ is a vector of individual and household characteristics including a rural dummy, education, marital status, number of kids and migration from East Germany after WWII as well as spousal characteristics such as spousal education and wage. $\varepsilon_{i r t}$ is a random, idiosyncratic error term.

\footnotetext{
${ }^{8}$ This paper provides evidence on the impact of wartime physical destruction using city-by-cohort variation in destruction within Germany; therefore this approach may yield lower bound estimates for the aggregate nation-wide effects of postwar mandatory employment on females' labor market outcomes in Germany.

${ }^{9}$ Since we will be using a single cross section, $\gamma_{t}$ accounts not only for year of birth but also for age effects.
} 
Following Bertrand, Duflo and Mullainathan (2004), the standard errors are clustered by city to account for correlations in outcomes between women residing in the same city over time.

In order to interpret $\beta$ as the effect of postwar reconstruction, we must assume that had WWII destruction not occurred, the difference in female labor market outcomes between the affected cohorts and cohorts that enter the labor market after the reconstruction period would have been the same across cities with varying intensity of destruction. More specifically, Equation (1) assumes that wartime physical destruction and subsequent reconstruction effort affected the labor market outcomes of the German working-age women born between 1920 and 1934 and has no impact on the earlier and later birth cohorts. To provide more formal evidence on cohort-specific effects of postwar reconstruction and test the parallel trend assumption, the identification strategy presented in Equation (1) can be generalized as follows (Duflo, 2001):

$$
\mathrm{Y}_{\text {irt }}=\alpha+\sum_{c=1}^{10}\left(\text { Destruction }_{r} \times \text { Cohort }_{i c}\right) \beta_{1 c}+\delta_{r}+\gamma_{t}+\pi^{\prime} \mathbf{X}_{\text {irt }}+\varepsilon_{i r t}
$$

where $\mathrm{Y}_{\text {irt }}$ is the outcome of interest for female $i$, in city $r$, born in year $t$. Cohort $_{i c}$ is a dummy variable that indicates, whether female $i$ was born in cohort $c$ (a cohort dummy). To increase statistical precision, birth cohorts are grouped into 5-year groups starting from 1905. Individuals born between 1955 and 1960 form the control group, and this cohort dummy is omitted from the regression. These unrestricted estimates in Equation (2) present the cohort-specific impacts of the wartime destruction and subsequent postwar mandatory employment. Thus, each coefficient $\beta_{1 c}$ can be interpreted as an estimate of the effects of wartime destruction on a given cohort. For the validity of the identifying assumption above, the effects of wartime destruction and subsequent reconstruction should be zero or negligible for the cohorts that are likely to be out of 
the labor force in 1978 (i.e., born between 1905 and 1919) and for cohorts that enter the labor market after the reconstruction was completed in late 1950s (i.e., born between 1940 and 1960).

In addition, to assess the validity of the parallel trend assumption, we use an alternative estimation strategy and instrument the city-level war destruction with distance to London where AAF airfields were mainly located. Due to their proximity to the U.K., cities in the northern and western parts of Germany suffered the most from the AAF aerial bombing during WWII. Distance from London, however could capture a wide range of factors including economic advantage and might affect women's long-term labor market outcomes through channels other than postwar reconstruction and mandatory employment. We assess the validity of our instrument in Section 5 by comparing cities' prewar characteristics by distance to London and find no variation across cities.

\section{Data and Descriptive Statistics}

The measure of WWII destruction intensity that we use for our main analysis is from Kaestner (1949), who reports the results of a survey undertaken by the German Association of Cities ("Deutscher Staedtetag"). Kaestner provides city-level information on the aggregate residential rubble in $m^{3}$ per capita in German cities by the end of WWII, which is what we use as a measure of a city's overall wartime destruction. ${ }^{10}$ In order to examine prewar city conditions and assess the mechanisms through which post-WWII reconstruction and mandatory employment might have affected long-run labor market outcomes of women, we gathered unique data from various years of the German Municipalities Statistical Yearbooks. First, we assembled city-level data on postwar female/male ratio, female share in industry, construction, service and

\footnotetext{
${ }^{10}$ Rubble arising from destruction of industrial buildings, inventories, machines and traffic facilities was not included in the calculations.
} 
public sectors, refugee and migrant share. Second, we collected city-level data on the loss of household savings and wealth during WWII and per capita war relief payments received by citizens after WWII. Additionally, we compiled data from 1939 German Municipalities Statistical Yearbook on prewar city characteristics including average income per capita, city area and population density.

The data on individual and household characteristics come from the confidential version of the German Microcensus. ${ }^{11}$ The German Microcensus includes $1 \%$ of the resident population in former West Germany, and is a large, representative, random sample containing comprehensive information on individual and household characteristics. We use data from the 1978, which is the first wave that reports female education and whether they were residing within the borders of West Germany in 1939. The German Microcensus also contains information on all household members and has a very high response rate of approximately $97 \%$. We restrict the main empirical analysis to women who were born between 1920 and 1954. We dropped women that were born between 1935 and 1939 from the analysis since they were partly exposed to WWII destruction. ${ }^{12}$ Moreover, cohorts born before 1920 were excluded from the main analyses due to the likelihood of being out of labor force in 1978. Additionally, in order to capture females that are active in the labor market, we exclude individuals who are students in 1978 from the analysis.

We consider WWII reconstruction impacts at the Raumordnungsregionen level ("ROR", or "city"). RORs are analogous to metropolitan statistical areas (MSAs) in the U.S., though, in contrast to MSAs, RORs also encompass rural areas; that is, all of Germany, regardless of

\footnotetext{
${ }^{11}$ Research Data Center (RDC) of the Federal Statistical Office of Germany and the Statistical Offices of the Laender, Microcensus 1978, own calculations.

${ }^{12}$ The results for the entire sample, where these 1935-1939 cohorts are added to the control group, are presented in Appendix Table 1. Point estimates tend to be smaller; this is not surprising since the control group now includes some cohorts that may have received partial treatment.
} 
urbanicity, belongs to an ROR. We restrict our analysis to former West Germany, for which we have the wartime destruction data. West Germany had 38 different Raumordnungsregionen in 1978 (see Figure 2 for detailed information on RORs). The Microcensus provides information on cities where individuals are residing in 1978. The Microcensus also asks respondents whether their residence was within the borders of former West Germany in 1939 and whether they have migrated from East Germany after WWII. We exclude from the analysis individuals who were residing outside of West Germany in $1939 .^{13}$

To form the final dataset used in the analysis, we recoded the raw data on war destruction using German regional boundaries (ROR) employed by the German Federal Office for Building and Regional Planning (Bundesamt für Bauwesen und Raumordnung, BBR) in 1978 and then merged it by ROR with the individual-level data from the German Microcensus. ${ }^{14}$ Table 1 presents the descriptive statistics for population-weighted city-level war destruction measures and variables measuring city's prewar and postwar conditions. In Section 5, we will evaluate the war effects at the average population-weighted rubble in $\mathrm{m}^{3}$ per capita. Table 1 shows that the average West German lived in a city that had a great deal of destruction-12.18 rubble in $m^{3}$ per capita and 37 percent of total housing units destroyed. There was variation across cities in destruction intensity; people in cities with above-average destruction had around three times the rubble per capita as people in cities with below-average destruction. Table 1 hints that highly destroyed cities are different from less destroyed cities. For example, highly destroyed cities are larger in area and have higher population density and average income per capita before WWII.

\footnotetext{
${ }^{13}$ The Microcensus also allows us to identify individuals who have migrated to East Germany during the war years and migrated back to West Germany after WWII. These individuals constitute less than 1 percent of our sample, nevertheless we account for them in our analysis.

${ }^{14}$ The data on rubble in $\mathrm{m}^{3}$ per capita is available for almost all municipalities with more than 12,000 inhabitants in 1939. To obtain the regional averages of all destruction measures, we merge municipalities in 1939 using 1978 regional borders. Each of these municipalities was part of current-day regions (RORs) in 1978.
} 
Therefore, relying only on cross-city variation in destruction makes it difficult to isolate the effects of participating mandatory employment on long-term labor market outcomes of women from other city-specific characteristics. The difference-in-differences strategy we propose uses within-city cross-cohort variation to identify the effects of postwar mandatory employment, and controls for differences between birth cohorts that are common across German cities. ${ }^{15}$

Table 2 shows the descriptive statistics of the outcomes and the main individual-level control variables we will use in our estimation. One of the main outcomes of interest is employment probability. We will also present results using full-time employment, part-time employment, hours worked and logarithm of monthly income. We will also analyze occupational choice of women. We use two different sets of measure for occupations. First, we calculate the average years of education attained by workers in each occupation. Then, we grouped occupation categories as low-skill, medium-skill and high-skill. Second, we categorized occupation as "female-concentrated" and "female-dominated" occupations. We define the occupation as "female-concentrated" if more than 40 percent of workers in this occupation are females. Similarly, "female-dominated" occupations are defined as occupations where females constitute the majority of the employees working in these occupations.

\section{Estimation Results}

\subsection{Female Employment and Hours Worked}

Table 3 reports the results of estimating Equation (1) where the dependent variable is female labor force participation. We coded individuals as employed if they report that their main

\footnotetext{
${ }^{15}$ There is a concern that the observed differences in levels of population density, city size and per capita income suggest possible differences in trends in women's outcomes. Below, we assess whether there are differential trends by presenting the empirical analysis from estimating Equation (2). In addition, we present the estimation analysis using instrumental variable in Section 5, which accounts for the potential cohort-specific postwar trends in outcomes.
} 
source of income is employment. We dropped individuals who are self-employed from the analysis. Each column is from a separate regression that controls for city and birth year fixed effects along with a rural dummy. The difference-in-differences estimate, $\beta$, is reported in the first row. It is negative and significant at the 99 percent level of confidence in every specification. Column (1) has an estimated $\beta$ of -0.0017 which suggests that working-age women in a city with average destruction are 2 percentage points less likely to be employed. This is the difference-in-difference coefficient $\beta(-0.0017)$ multiplied by the average population-weighted rubble in $\mathrm{m}^{3}$ per capita $\left(12.18 \mathrm{~m}^{3}\right)$ in Table 1 . To gain a better understanding on the magnitude of $\beta$, we can also compare the employment probability of rubble women who were in Cologne (a heavily destroyed city with $25.25 \mathrm{~m}^{3}$ rubble per capita) to rubble women who were in Munich (a less destroyed city with $6.50 \mathrm{~m}^{3}$ rubble per capita) during WWII. ${ }^{16}$ Using this comparison, column (1) suggests that rubble women in Cologne are 3 percentage points less likely to work compared to women in Munich as a result of higher wartime destruction. ${ }^{17}$

Columns (2) and (3) of Table 3 present the analyses incorporating individual and household characteristics, such as years of schooling, marital status, number of kids, whether an individual moved from East Germany after WWII, wage and years of schooling of household head, which are important factors determining female labor force participation decision. The difference-in-difference estimates in Columns (2) and (3) are quantitatively similar to the baseline specification which supports the interpretation of the difference-in-difference estimates as due to postwar mandatory employment as opposed to omitted variables.

\footnotetext{
${ }^{16}$ These two cities were very similar in terms of their prewar characteristics, but Cologne was closer to bomber aerial fields in London and therefore exposed to higher levels of destruction during WWII.

${ }^{17}$ The official unemployment rate quoted by the German Labor Agency was 5.4 percent among women in 1978; thus it is unlikely that there was a shortage in terms of job availability for women in 1978.
} 
Results presented in Table 3 rest on the assumption that in the absence of postwar reconstruction, the difference in female labor force participation between the affected group and the later birth cohorts would have been similar across cities with varying intensity of destruction (which is known as parallel trend assumption). Figure 3 presents the cohort-specific impacts of the participating in postwar reconstruction which enable us to identify the birth cohorts mostly impacted from the postwar mandatory employment. Additionally, Figure 3 allows us to formally test the identifying assumption in Equation (1) which assumes that the negative effects of postwar employment law are only present for the birth cohorts that were of working age during the reconstruction years. To increase statistical precision, in Figure 3, birth cohorts are grouped into 5-year groups starting from 1905. Individuals born between 1955 and 1960 form the control group, and this cohort dummy is omitted from the regression. Figure 3 shows that exposure to postwar reconstruction has substantially reduced the employment probability of women born between 1920 and 1934. Cohorts born between 1920-1924 and 1925-1929 are on average 2 and 3 percentage points less likely to work in 1978 , respectively due to the war devastation and the subsequent reconstruction effort. Figure 3 further reveals that the adverse effects of the war shock are also present for cohorts born between 1930 and 1934, where women in this cohort have 5 percentage points lower employment probability on average two decades after the end of the postwar reconstruction. Additionally, Figure 3 reports that participating in postwar reconstruction and rubble removal has no effect on the employment probability of earlier and later birth cohorts. ${ }^{18}$ This supports the aforementioned identifying assumption and suggests that the estimation results presented in Table 3 are not confounded by the city-specific prewar and postwar cohort trends.

\footnotetext{
${ }^{18}$ Notable exception is the cohort born between 1934 and 1939. Figure 3 shows that individuals born between 1934 and 1939 were partially impacted from wartime destruction; therefore we dropped them from the analysis.
} 
An additional concern for the parallel trend assumption is that WWII destruction may be endogenous to trends in female labor market outcomes, or the postwar reconstruction effort may be endogenous. That is, it is possible that the postwar reconstruction effort were unevenly allocated towards cities with better growth prospects. Additionally, industrial composition may have changed in postwar Germany. To address these potential concerns, we employ an instrumental-variable strategy in addition to controlling for the change in the demand for female labor in each industry in Table 8 . The instrumental variable that we use for a city's wartime physical destruction is the city's distance to London obtained using the Geographic Names Information System (GNIS). As stated in Section 2, cities in the northern and western parts of Germany suffered the most from the AAF aerial bombing. Table 4 reports instrumental-variable estimates for female employment. ${ }^{19}$ The lower panel in Table 4 shows that the first-stage estimates are statistically significant at 1 percent significance level suggesting that cities closer to London indeed experienced more destruction as a result of AAF aerial raids, consistent with the foregoing historical records. The results from estimating Equation (1) using two-stage least squares are given in upper panel of Table 4. The 2SLS estimate in Column (1) indicates that on average rubble women are 4 percentage points less likely to work in 1978 as a result of postwar mandatory employment; this is almost twice the size of the original difference-in-difference estimates though it should be noted that the standard errors for the 2SLS estimates are large. Similar to difference-in-difference analysis, in Columns (2) and (3), we control for individual and household characteristics. The 2SLS coefficients in these columns suggest that working-age women who have participated in the rubble removal and reconstruction efforts are 7 percentage points less likely to be employed in 1978 on average after controlling for individual and

\footnotetext{
${ }^{19}$ To assess whether the proposed instrumental-variable satisfies the exclusion restriction, we compared cities closer to and far away from London in terms of their prewar city characteristics. We find no significant difference in prewar city characteristics across cities by their distance to London.
} 
household characteristics. Results presented in Table 4 bolster the idea that city's war damage is exogenous once we control for fixed city characteristics.

In Table 3 and Table 4, we focused on women's employment without differentiating between full-time and part-time employment. However, women are historically more likely to work in part-time jobs; therefore it is likely that exposure to wartime destruction and subsequent reconstruction has differential effects on female employment depending on the type of employment. In order to capture differential dynamics of full-time and part-time employment, in Table 5, we focus only on women who reported that they work full-time. The treatment and control groups described above for the employment analysis also apply for this outcome, as Figure 4 also suggests. In Table 5, all specifications show that women who were actively involved in the removal of rubble and reconstruction after WWII are less likely to hold full-time jobs in the long-run. In Column (1), the difference-in difference estimate is -0.0014 indicating that rubble women are on average about 2 percentage points less likely to work full-time than the others. We find quantitatively similar results in Columns (2) and (3) when we incorporate individual and household characteristics into baseline specification. As robustness to the difference-in-difference results, we report 2SLS analysis in Columns (4)-(6) using city's distance to London as an instrument for city's wartime destruction. The 2SLS estimate in Column (4) indicates that exposure to wartime destruction has reduced rubble women's likelihood of working in a full-time job by 3 percentage points. The 2SLS coefficient almost doubles in magnitude in Columns (5) and (6) after incorporating individual and family background characteristics into the analysis. Taken together, findings summarized in Table 5 suggest that rubble women experienced a considerable drop in their labor market attachment after the postwar reconstruction period was over. 
Now, we turn to estimating the impact of postwar mandatory employment on part-time employment of women. Similar to other developed countries, women in Germany are more likely to work in part-time jobs; therefore it is likely that women working in part-time jobs were differentially impacted from participating in postwar reconstruction. In this analysis, we coded women as working part-time if they work 20 hours or less per week. Table 6 presents the results for part-time employment from the difference-in-difference and instrumental variable analysis. The results reported in Table 6 provide suggestive evidence that postwar reconstruction caused German women who were of working-age during reconstruction era to hold part-time jobs in the future; however, none of the effects are statistically significant at the conventional level.

Finally, Table 7 estimates the effect of postwar mandatory employment on the intensive margin of female labor supply. The outcome of interest in Table 7 is weekly hours worked. The treatment and control groups described above for the employment analysis also apply for this outcome, as Figure 5 also suggests. The difference-in-difference estimates reported in the first three columns indicate that exposure to wartime destruction and follow-up reconstruction efforts reduces weekly hours worked by women between 0.8 and 0.9 hours per week on average in the future. Similarly, 2SLS results reported in Columns (4)-(6) further suggest that rubble women in a city with average wartime destruction work between 2.1 and 2.8 fewer hours per week on average. Evidence presented in Table 7 therefore suggests that the detrimental effects of postwar mandatory employment on female labor supply are not only limited to the participation decision. It seems that women who were affected from the mandatory employment after WWII are not only less likely to work in the future, but also they work for fewer hours even if they are active in the labor market. ${ }^{20}$

\footnotetext{
${ }^{20}$ Another potential outcome of interest is monthly income. Unfortunately, monthly income variable in the German Microcensus is reported in wide brackets which renders statistical inference challenging. We present the difference-
} 
Having shown that exposure to postwar reconstruction has long-lasting adverse effects on the intensive and extensive margins of female labor supply; it is of interest to explore the channels underlying this causal association. Is the estimated effect of postwar reconstruction on female employment working through channels affecting labor demand function such as increase in demand for female labor in traditionally male-dominated occupations in the absence of men? Are labor supply side factors such as changes in gender roles, composition of population and household wealth at work? In Table 8, we provide formal evidence on the mechanisms through which postwar mandatory employment may have affected the rubble women's employment decision in the long-run. This table mimics the specification in Column (3) in the previous tables which is the most unrestrictive specification incorporating individual and spousal characteristics along with wartime physical destruction. The first row in Table 8 reports the difference-indifference coefficient for the rubble in $m^{3}$ per capita controlling for potential labor supply and labor demand factors.

One of the potential channels underlying our findings is war-induced change in the female/male ratio in postwar Germany. As discussed in Section 2, a substantial fraction of German male population was lost during WWII, due to war casualties and being captured as prisoners of war increasing the demand for female labor for postwar reconstruction and rubble removal (Heineman, 1996; Meiners, 2011). Even though the male population declined in the entire country, some cities might have experienced a greater decrease in their male population; thus the need for female labor might have been higher in these cities regardless of the amount of wartime destruction in the city. As an attempt to control for potential differences in the postwar

in-difference and instrumental variable analyses in Appendix Table 1 where the outcome of interest is logarithm of monthly income. We find that participating in postwar mandatory employment has no long-term effects on women's monthly income; however these analyses warrant caution because of the structure of the income question in the Microcensus. 
femalelmale ratio, we include the interaction between city-level female/male ratio in 1946 and an indicator for being in the affected group in our analysis.

Another related channel may be the differential change in the postwar industrial composition. Due to heavy aerial attacks, along with residential areas, a substantial fraction of the German industry was also destroyed during WWII. With the Marshall Plan, Germany regained its industrial capacity by the early 1960s, where new plants and factories were established and destroyed ones were rebuilt with the help of rubble women. However, more female-dominated industries such as service and public sectors might have been developed in some cities, while others experiencing an upsurge in industry and construction sectors. We address this potential concern in our instrumental variable analysis; however, as robustness, in Table 8, we provide further evidence on whether changes in the industrial composition explain our results. We collected city-level data on female share in industry, construction, service and public sectors in 1953 and $1963 .{ }^{21}$ Using this information, we generated city-level variables presented in rows (3)-(6) in Table 8 which measure the change in the female representation in industry, construction, service and public sectors between 1953 and 1963, respectively. These variables help us capture the potential industry-specific changes in the demand for female labor in each city.

Now, we turn to supply side factors. One of the potential supply side factors is the change in the household wealth during and after WWII. As income-leisure theory suggests, this decrease in savings and wealth would induce a higher number of women to seek employment to support their family as a main breadwinner or an added worker. To account for the changes in household wealth, we assembled a unique city-level data on the average per capita household savings loss

\footnotetext{
${ }^{21}$ The city-level data on female share in each industry is available only in 1953 and 1963; therefore we use these years in our analysis.
} 
during WWII and average per capita war relief payments distributed after WWII. Using this information, we control for the interaction between saving loss during WWII and war relief payments and being in the affected cohort in our analysis.

Another related channel is the change in the composition of the population. First potential source for this change is refugees or people who fled to Germany from the former parts of Germany and Soviet Zone/GDR after WWII. It is possible that refugees might have settled in cities with less wartime destruction. As an attempt to address this potential concern, we use information from the German Microcensus on whether an individual is a refugee card holder in $1978{ }^{22}$ Using this information, we generated an average share of refugees in each city in 1978. The second source for population change is migration. Starting 1970s, Germany invited approximately 3 million "guest workers" from southern Europe (Spain, Italy, and Greece), the former Yugoslavia and Turkey. To account for this potential concern, we have calculated the average migration share in each city in 1978. Using the interaction of these two city-level measures of population change and being in the affected cohort, we address the potential impacts of the change in population on female labor supply.

In Table 8, we find that women are more likely to work part-time and less likely to hold full-time jobs and work longer hours if they have a more generous war relief payments from the government. Similarly, the amount of savings loss during WWII increased women's full-time employment and employment in general. Moreover, the last row in Table 8 shows that rubble

\footnotetext{
${ }^{22}$ Luettinger (1986, p.21-22) suggests that in the German displaced persons law passed in 1953, refugees are defined as the individuals who migrated from the Soviet Zone/GDR (Fluechtlingsausweis C, refugee card C). On the other hand, according to the same law, displaced people are subdivided into two groups as follows: (a) displaced individuals who lived in the Eastern regions on 1.1.1937 (Vertriebenenausweis A, displaced person card A) (b) displaced individuals who lived in the German Eastern regions on 1.1.1939 (Vertriebenausweis B, displaced person card B). Moreover, the German displaced persons law applies not only to the original refugees and displaced people but also to the individuals who were born in the refugee and displaced households after the displacement. The status therefore is transferred over generations through birth.
} 
women residing in cities with a higher percentage of refugees are more likely to have full-time jobs and work for longer hours in the long-run. However, the difference-in-difference estimates

for the rubble in $m^{3}$ per capita presented in the first row remain to be economically and statistically significant in all four columns. By and large, findings presented in Table 8 suggest that the mandatory employment during postwar reconstruction period has adverse effects on the extensive and intensive margins of female labor supply in the long-term even after we account for the potential supply and demand side factors that might have impacted their labor market decision. A mental and physical exhaustion from working in challenging conditions and an increase in marriage and fertility rates after the reconstruction period left standing as potential mechanisms explaining our results. In Appendix Table 3, we indeed find that marriage rates have increased in cities with higher wartime destruction after WWII. Moreover, we find suggestive evidence on increasing postwar fertility rates; however these results warrant caution since the Microcensus only provides information on the number of children still residing within the same household as their mothers. Therefore, it is likely that we focus on a selective group in our fertility analysis.

\subsection{Occupational Choice}

In this subsection, we analyze the effects of postwar mandatory employment on occupational choice of women. As discussed in Section 2, in postwar Germany, Law Nr.32 led "rubble women" to enter the labor force and work in professions which were previously closed to them. Therefore, it is possible that the postwar mandatory employment of women in traditionally male-dominated occupations may have provided them an opportunity to acquire skills and knowledge that are rewarded in the labor market. Additionally, women who worked during 
reconstruction period may have potentially increased their information about the available jobs in the manufacturing sector, increasing promotion and employment opportunities for them in the future. Alternatively, the wide-spread female labor force participation in postwar Germany might have altered the perceptions and preferences of women and encouraged them to continue working in traditionally male-dominated jobs even after the mandatory employment was abolished.

The outcome of interest in Table 9 is women's last occupation by skill-levels. We use information on workers' average years of schooling in each 3-digit occupation to determine the skill-level required for the jobs. ${ }^{23}$ An occupation is defined as "low-skill" if the workers' average years of schooling in this occupation is 9 years or less (which is the lowest level of educational attainment in Germany). In "medium-skill" occupations, workers' average years of schooling is between 10 and 14 years which correspondents to the completion of a technical high school (in German Real Schule) or academic-track high school (in German Gymnasium). Finally, we define occupations as "high-skill" if workers in this occupation have 15 years of schooling or more on average, which refers to some college education or more. The treatment and control groups described above for female labor supply also apply for the occupation outcomes, too.

In Column (1), the difference-in-difference estimate for "low-skill" occupation is -0.0014 which suggests that rubble women who were in a city with an average postwar reconstruction are 1.7 percentage points less likely to work in low-skill jobs in the long-run. On the other hand, 2SLS results presented in Column (4) indicates that women's representation in low-skill jobs decreased by 7.3 percentage points on average due to postwar reconstruction. The outcome of interest in Column (2) is the probability of working in a "medium-skill" occupation. We find that

\footnotetext{
${ }^{23}$ Occupation categories in the Microcensus are very similar to 3-digit categorization of occupations. There are 275 occupation categories listed in the data.
} 
mandatory employment in rubble removal and postwar reconstruction has increased the women's likelihood of working in occupations that require a technical or academic-high school degree. The difference-in-difference estimate reported in Column (2) points out that rubble women have 2 percentage points higher probability of holding a "medium-skill" job on average in the longrun. 2SLS analysis summarized in Column (4) supports the difference-in-difference results. 2SLS coefficient suggests that women's presence in medium-skill occupations increased by 7.7 percentage points as a result of mandatory employment. Finally, in Columns (3) and (6), we focus on the impact of postwar reconstruction on the likelihood of holding a high-skill job. The difference-in-difference and 2SLS analysis reported in Columns (3) and (6) indicate that postwar mandatory employment law has no or limited effects on the probability of working in high-skill jobs in the long-run.

In Table 10, we investigate how women's participation in postwar reconstruction has impacted the gender segregation in the occupations in the long-run. We grouped 3-digit occupation categories by their sex composition. An occupation is defined as "female concentrated" if females constitute more than $40 \%$ of all employees working in this occupation. Similarly, we define occupations as "female-dominated" if more than half of all employees working in these occupations are females. Table 10 reveals that mandatory employment after WWII has increased women's presence in female-dominated occupations in general. The difference-in-difference estimates in the first two columns indicate that rubble women in a city with an average wartime destruction are 1.2 percentage points more likely to work in femaledominated occupations. Similar to the difference-in-difference estimates, 2SLS estimates presented in Column (3) and (4) suggest that participating in postwar reconstruction increased the likelihood of rubble women to work in female-dominated jobs by 2.1 percentage points on 
average. As we mention in Section 2, women were restricted to certain professions such as teaching or working in agriculture before WWII. With an increasing demand for female labor in postwar era, women started to take part in traditionally male-dominated occupations. However, findings in Table 10 provide evidence suggesting that rubble women were selected into certain traditionally male-dominated occupations in large numbers in postwar era and outnumbered men in these occupations over time. Moreover, our findings hint that female presence in the majority of male-dominated jobs is still limited two decades after postwar mandatory employment law was abolished.

Table 11 presents the analysis controlling for potential labor supply and labor demand factors that might have influenced women's occupational choice. It seems that an increase in the female share in industry between 1953 and 1963 reduced their likelihood of working in low-skill jobs, while increasing female presence in medium-skill and female-dominated jobs. The generosity of the war relief payments has similar effects as an increase in female share in industry. Women in cities with more generous per capita war relief payments are more likely to work in medium-skill and female-dominated jobs compared to others. On the other hand, the last row in Table 11 shows that rubble women residing in cities with a higher percentage of refugees are less likely to work in medium-skill and female-dominated jobs in the long-run. However, the difference-in-difference estimates for the rubble in $m^{3}$ per capita presented in the first row remain to be economically and statistically significant in all columns after controlling for potential channels underlying our results. 


\section{Conclusion}

This paper presents causal evidence on the consequences of large-scale physical destruction arising from WWII and subsequent reconstruction efforts on women's long-term labor market outcomes. The findings in this paper shed light on the potential long-term legacies of large-scale physical destruction and follow-up reconstruction efforts that could be caused by hurricanes, earthquakes, floods and armed conflicts. We combine a unique dataset on city-level WWII destruction with individual-level data from the German Microcensus to study the long-run effects of postwar mandatory employment on labor market outcomes of women in Germany. The identification strategy exploits plausibly exogenous city-by-cohort variation in the intensity of WWII destruction. We find that postwar reconstruction reduced female labor force participation and hours worked in the long-run. However, our results show that participating in postwar reconstruction efforts increased the female presence in medium-skill and female-dominated occupations even two decades after the postwar mandatory employment law was abolished. These results survive after we account for labor supply side factors such as per capita wealth and savings loss during WWII, per capita war relief payments and refugee and migrant share and labor demand side factors such as female share in industry, construction, service and public sectors. A mental and physical exhaustion from working in challenging conditions and increase in marriage and fertility rates after reconstruction period are potential mechanisms explaining our results.

In addition, given that the adverse effects of postwar mandatory employment are still present two decades after this law was abolished, our results suggest that work-contingent income support programs widely implemented in developed countries recently will likely have no positive or even negative effects on female labor market outcomes and welfare dependency in 
the long-run. Our findings suggest that mandatory employment in postwar Germany led to psychological and physical fatigue among women and discouraged them from continue working after the mandatory labor law was abolished. Therefore, our findings raise questions on the effectiveness of work-contingent income support programs in increasing female labor market attachment in the long-run. 


\section{References}

Acemoglu, Daron, David H. Author and David Lyle. 2004. "Women, War, and Wages: The Effect of Female Labor Supply on the Wage Structure at Midcentury." Journal of Political Economy, 112(3): 497-551.

Akbulut-Yuksel, Mevlude. 2009. "Children of War: The Long-Run Effects of Large-Scale Physical Destruction and Warfare on Children," IZA Discussion Paper 4407.

Allied Control Authority Germany. 1946. Enactments and Approved Papers. Vol.2, Jan.-Feb. 1946. The Army Library. Washington D.C.

Bertrand, Marianne, Esther Duflo and Sendhil Mullainathan. 2004. "How much should We Trust Difference-in-Difference Estimates?” Quarterly Journal of Economics, 119 (1): 249-275.

Blattman, Christopher and Edward Miguel. 2010. "Civil War." Journal of Economic Literature, 48(1): 3-57.

Brakman, Steven, Harry Garretsen, and Marc Schramm. 2004. "The Strategic Bombing of Cities in Germany in World War II and its Impact on City Growth." Journal of Economic Geography, 4(1): 1-18.

Card, David and Dean R. Hyslop. 2005. "Estimating the Effects of a Time-Limited Earnings Subsidy for Welfare Leavers." Econometrica, 73 (6): 1723-1770.

Davis, Donald and David Weinstein. 2002. "Bones, Bombs, and Break Points: The Geography of Economic Activity.” American Economic Review, 92 (5): 1269-1289.

Diefendorf, Jeffry. 1993. In the Wake of the War: The Reconstruction of German Cities after World War II. New York: Oxford University Press.

Donath, Svenja. 2008."Von der Truemmerfrau zum Heimchen am Herd." Kritische Ausgabe, 8: $20-22$.

Duflo, Esther. 2001. "Schooling and Labor Market Consequences of School Construction in Indonesia: Evidence from an Unusual Policy Experiment." American Economic Review, 91 (4): 795-813.

Eissa, Nada and Hillary W. Hoynes. 2004. "Taxes and the Labor Market Participation of Married Couples: The Earned Income Tax Credit." Journal of Public Economics, 88 (9-10): 1931-1958.

Eissa, Nada and Hillary W. Hoynes. 1998. "The Earned Income Tax Credit and the Labor Supply of Married Couples", NBER Working Paper 6856. 
Eissa, Nada and Jeffrey B. Liebman. 1996. "Labor Supply Response to the Earned Income Tax Credit." Quarterly Journal of Economics, 111 (2): 605-637.

Friedrich, Joerg. 2002. Der Brand: Deutschland im Bombenkrieg, 1940-1945. Munich: Propylaen Publishing.

Goldin, Claudia. 1991. "The Role of World War II in the Rise of Women's Employment." American Economic Review, 81 (4): 741-56.

Grayling, Anthony. 2006. Among the Dead Cities: Was the Allied Bombing of Civilians in WWII a Necessity or a Crime?. London: Bloomsbury.

Heineman, Elizabeth. 1996. "The Hour of the Woman: Memories of Germany's "Crisis Years" and West German National Identity." The American Historical Review, 101 (2): 354-395.

Hoehn, Maria. 1997."Stunde Null der Frauen? Renegotiating Women's Place in Postwar West Germany." In Stunde Null: The End and the Beginning Fifty Years Ago, Geoffrey Giles (eds), German Historical Institute, Washington DC, Occasional Paper 20.

Hotz, V. Joseph, Charles H. Mullin, and John K. Scholz. 2006. "Examining the Effect of the Earned Income Tax Credit on the Labor Market Participation of Families on Welfare", NBER Working Paper 11968.

Jenk, Gabriele. 1988. Steine gegen Brot. Truemmerfrauen schildern den Wiederaufbau in der Nachkriegszeit. Gustav Luebbe Verlag, Bergisch Gladbach.

Kästner, Friedrich. 1949. "Kriegsschäden: Trümmermengen, Wohnungsverluste, Grundsteuerausfall und Vermögensteuerausfall." Statistisches Jahrbuch Deutscher Gemeinden, 361-391.

Luettinger, Paul. 1986. "Der Mythos der schnellen Integration: Eine empirische Untersuchung zur Integration der Vertriebenen und Fluechtlinge in der Bundesrepublik Deutschland bis 1971." Zeitschrift fuer Soziologie, 15 (1): 20-36.

Meiners, Antonia. 2011. Wir haben wieder aufgebaut: Frauen der Stunde null erzaehlen. Elisabeth Sandmann Verlag GmbH. Muenchen.

Menon, Nidhiya and Yana van der Meulen Rodgers. 2011. "War and Women's Work: Evidence from the Conflict in Nepal," World Bank Policy Research Paper 5745.

Meyer, Bruce D. and Dan T. Rosenbaum. 2000. "Making Single Mothers Work: Recent Tax and Welfare Policy and Its Effects." NBER Working Paper 7491.

Miguel, Edward and Gerard Roland. Forthcoming. "The Long Run Impact of Bombing Vietnam." Journal of Development Economics. 
Moeding, Nori. 1988. "Die Stunde der Frauen: Frauen und Frauenorganisationen des buergerlichen Lagers." In Von Stalingrad zur Waehrungsreform. Zur Sozialgeschichte des Umbruchs in Deutschland. Broszat, Martin, Klaus-Dietmar Henke and Hans Woller (eds.), Muenchen, p. 619-647.

New York Times. 2011. "Women Nudged Out of German Workforce." 29" June 2011. http://www.nytimes.com/2011/06/29/world/europe/29iht-FFgermany29.html

Nimmesgern, Susanne. 1997."Frauenarbeit zwischen Wandel und Tradition: Zur Entwickling der weiblichen Erwerbstaetigkeit in der Nachkriegszeit." In Grenz-Fall: das Saarland zwischen Frankfreich und Deutschland 1945-1960, Rainer Hudemann (eds.), St. Ingbert, 359-378.

Research Data Center (RDC) of the Federal Statistical Office of Germany and the Statistical Offices of the Laender, Microcensus 1978, own calculations.

Ruhl, Klaus-Joerg. 1994. Verordnete Unterordnung: Berufstaetige Frauen zwischen Wirtschaftswachstum und konservativer Ideologie in der Nachkriegseit (1945-1963). R. Oldenbourg Verlag. Muenchen.

Shemyakina, Olga. 2011. "Labor Market, Education and Armed Conflict in Tajikistan." Georgia Institute of Technology, mimeo.

Statistisches Bundesamt Wiesbaden. 1972. Bevoelkerung und Wirtschaft 1872-1972.

Unruh, Trude (Hrsg.). 1987. Truemmerfrauen: Biografien einer betrogenen Generation. Klartext-Verlag.

USSBS. 1945. The United States Strategic Bombing Survey: The Effects of Strategic Bombing on the German War Economy. Washington, DC: Overall Economic Effects Division 
Figure 1: Share of Dwellings Destroyed in German Cities during WWII

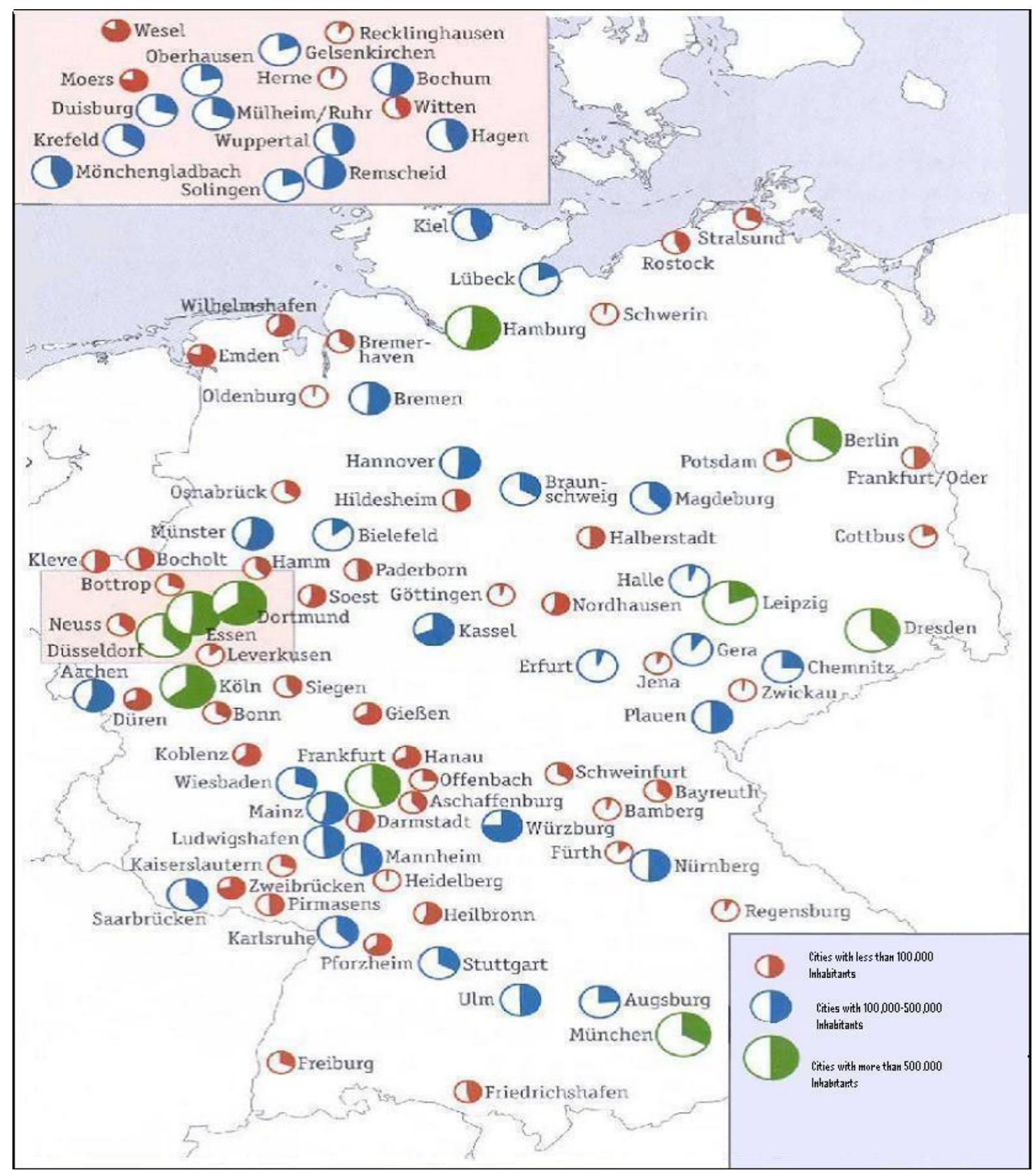

Source: Knopp (2001). The size of the circle shows the city size in 1939, where the largest circle refers to cities with more than 500,000 inhabitants; middle-size circle, cities with between 100,000 and 500,000 inhabitants and smallest circle, cities with less than 100,000 inhabitants. The shaded area in these circles is the share of the dwellings destroyed in the city by the end of WWII. 
Figure 2: Map of Raumordnungsregionen (RORs or Cities) in Former West Germany

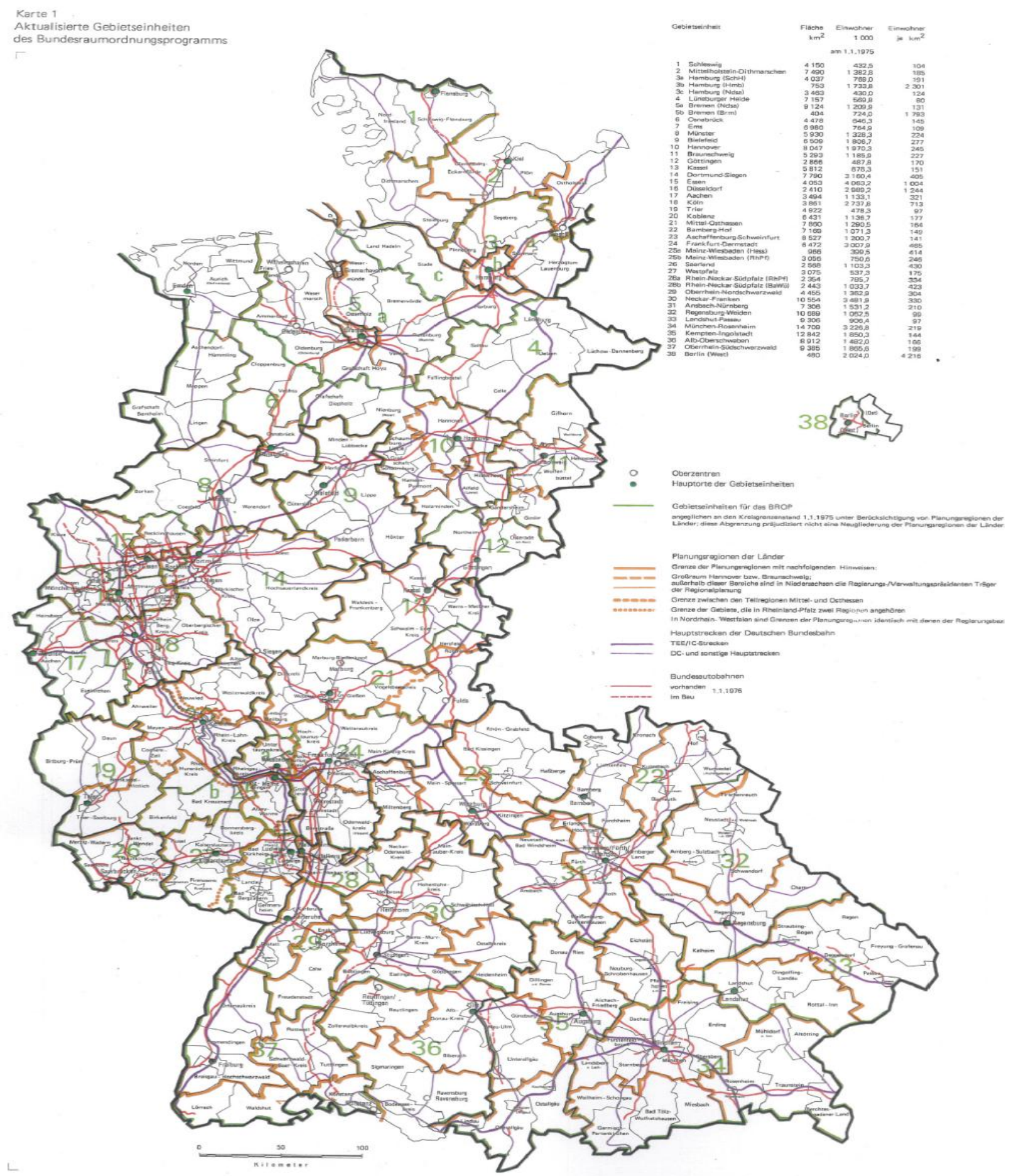

Source: Federal Office for Building and Regional Planning (Bundesamt für Bauwesen und Raumordnung, BBR). There are 38 regional policy regions (RORs) in former West Germany in 1978. 
Figure 3. Effect of Postwar Mandatory Employment on Female Employment by Cohort

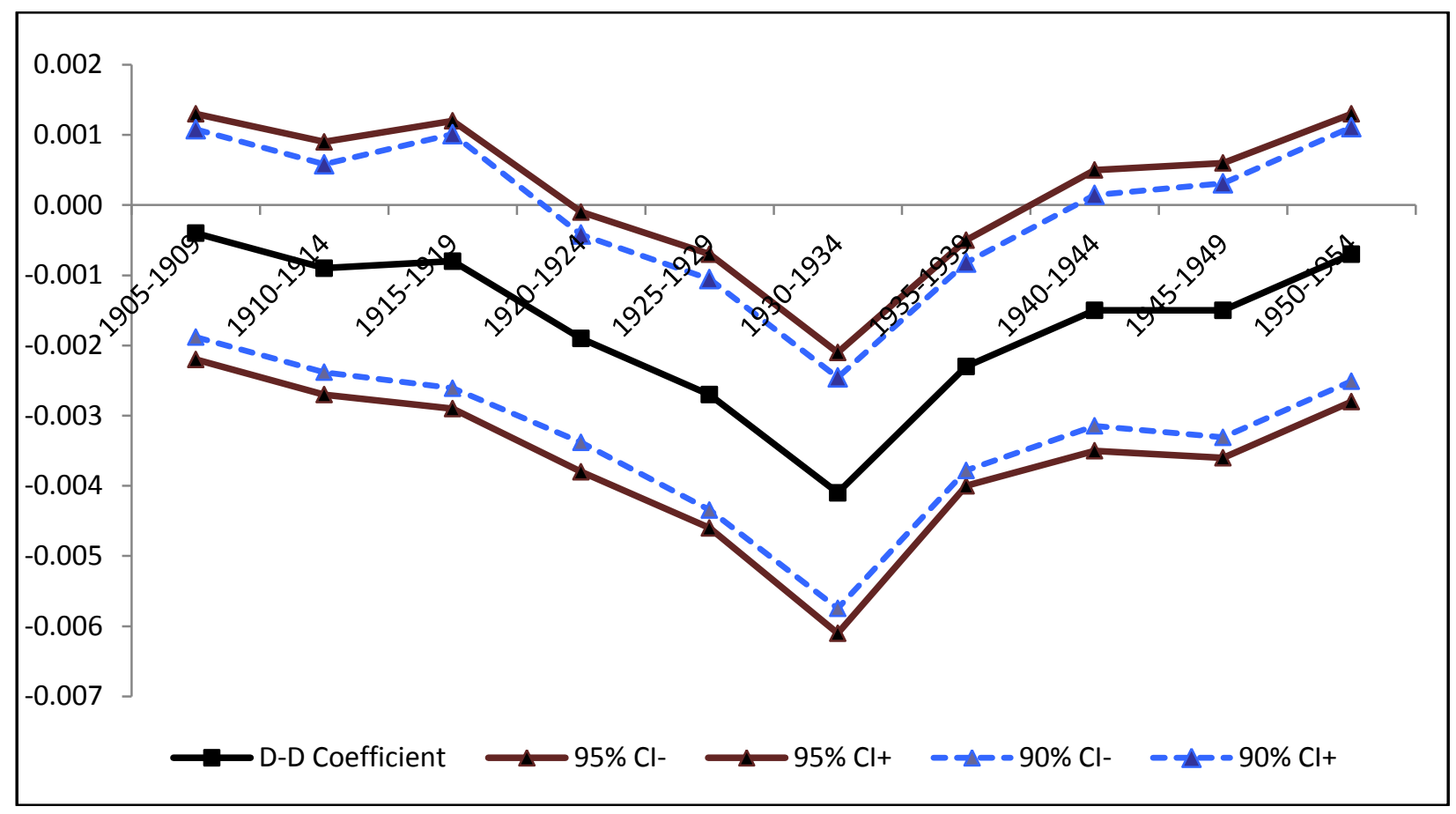

Figure 4. Effect of Postwar Mandatory Employment on Female Full Employment by Cohort

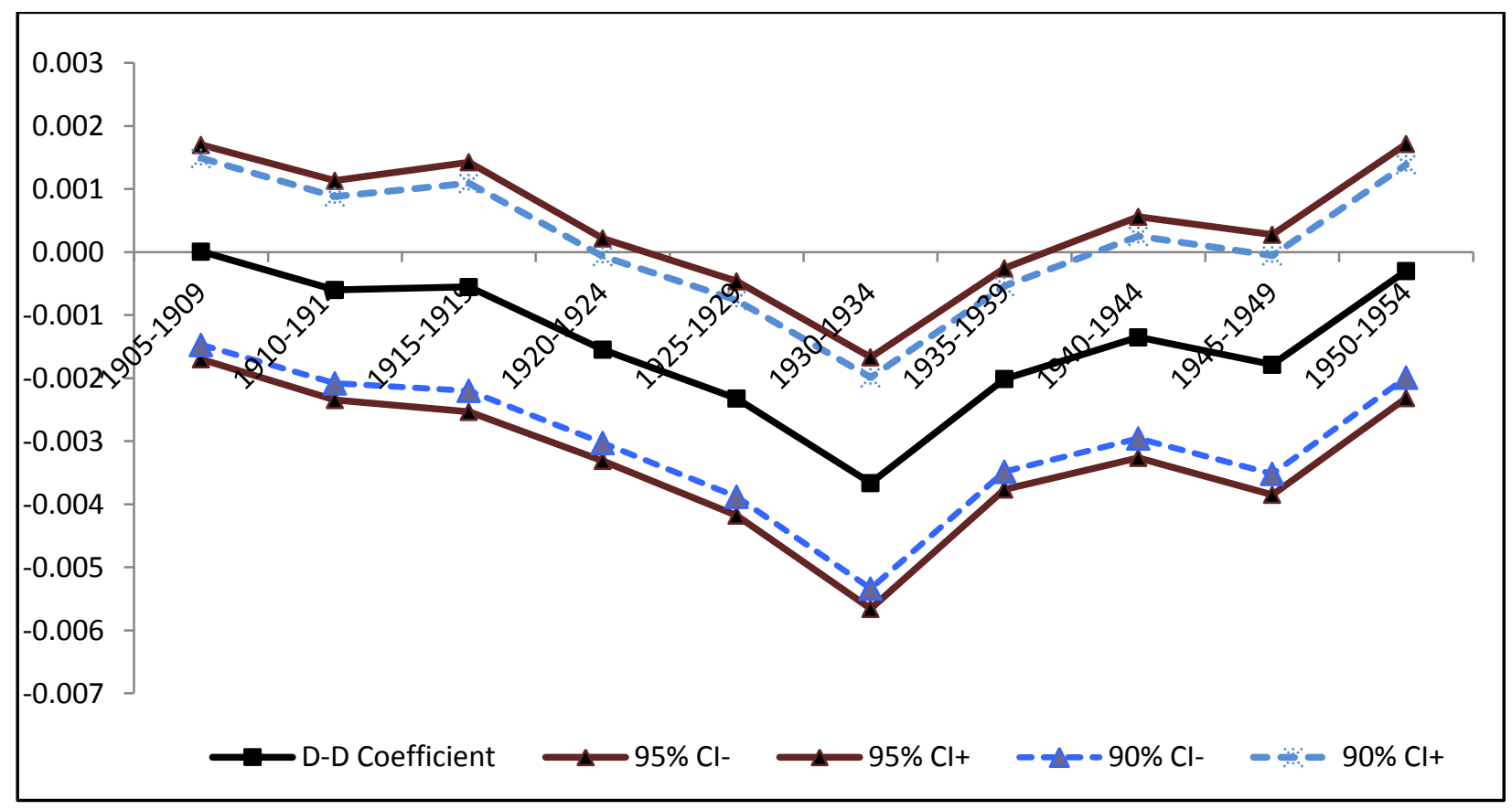


Figure 5. Effect of Postwar Mandatory Employment on Hours Worked by Cohort

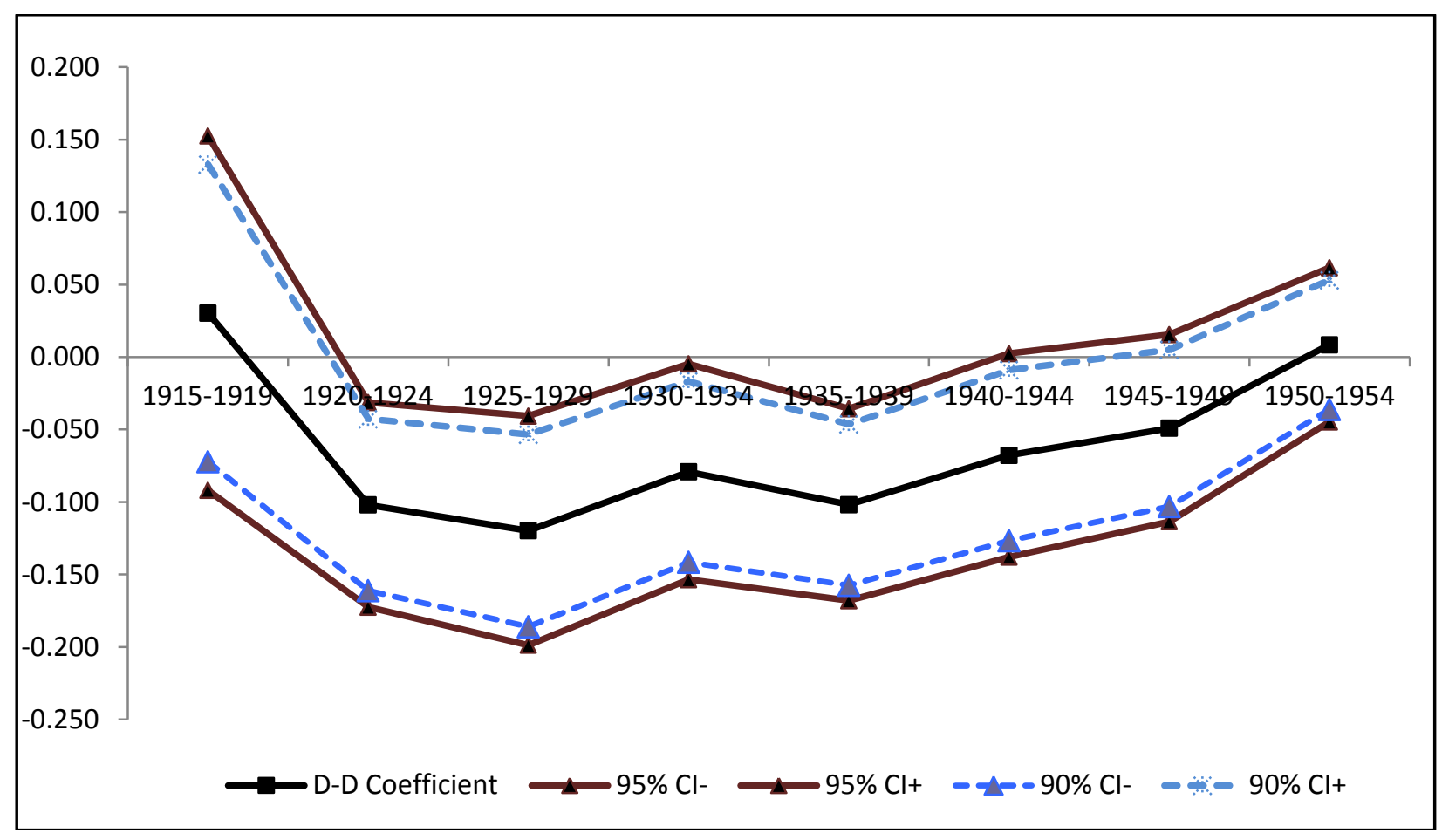


Table 1. Descriptive Statistics for WWII Destruction

\begin{tabular}{|c|c|c|c|c|c|}
\hline & All & $\begin{array}{l}\text { Cities with Above } \\
\text { avg. Destruction }\end{array}$ & $\begin{array}{l}\text { Cities with Below } \\
\text { avg. Destruction }\end{array}$ & $\begin{array}{c}\text { Difference } \\
\text { s.e (Difference) }\end{array}$ & \\
\hline & $(1)$ & $(2)$ & $(3)$ & $(4)$ & \\
\hline Rubble in $m^{3}$ per Capita & $\begin{array}{l}12.183 \\
(7.201)\end{array}$ & $\begin{array}{l}18.487 \\
(4.446)\end{array}$ & $\begin{array}{c}6.425 \\
(3.419)\end{array}$ & $\begin{array}{l}12.062 \\
(0.133)\end{array}$ & $* * *$ \\
\hline Housing Units Destroyed (\%) & $\begin{array}{c}37.224 \\
(18.557)\end{array}$ & $\begin{array}{c}49.706 \\
(12.143)\end{array}$ & $\begin{array}{c}25.823 \\
(15.874)\end{array}$ & $\begin{array}{l}23.882 \\
(0.479)\end{array}$ & $* * *$ \\
\hline Total bombs dropped in tons & $\begin{array}{c}25,036 \\
(22,507.660)\end{array}$ & $\begin{array}{c}36,333 \\
(25,566.010)\end{array}$ & $\begin{array}{c}14,717 \\
(12,223.020)\end{array}$ & $\begin{array}{c}21,616 \\
(664.975)\end{array}$ & $* * *$ \\
\hline Area in $\mathrm{km}^{2}$ in 1938 & $\begin{array}{c}253.296 \\
(238.281)\end{array}$ & $\begin{array}{c}359.747 \\
(292.370)\end{array}$ & $\begin{array}{c}156.060 \\
(103.811)\end{array}$ & $\begin{array}{c}203.687 \\
(7.255)\end{array}$ & $* * *$ \\
\hline Population density in 1939 & $\begin{array}{c}2,011 \\
(909.237)\end{array}$ & $\begin{array}{c}2,218 \\
(946.585)\end{array}$ & $\begin{array}{c}1,821 \\
(829.899)\end{array}$ & $\begin{array}{c}397 \\
(29.881)\end{array}$ & $* * *$ \\
\hline $\begin{array}{l}\text { Income per Capita in RM } \\
\text { in } 1938\end{array}$ & $\begin{array}{c}467.317 \\
(106.305)\end{array}$ & $\begin{array}{l}501.933 \\
(68.110)\end{array}$ & $\begin{array}{c}432.556 \\
(124.841)\end{array}$ & $\begin{array}{l}69.377 \\
(3.760)\end{array}$ & $* * *$ \\
\hline Distance to London in miles & $\begin{array}{l}419.062 \\
(88.413)\end{array}$ & $\begin{array}{l}394.324 \\
(82.205)\end{array}$ & $\begin{array}{l}441.657 \\
(87.854)\end{array}$ & $\begin{array}{l}-47.333 \\
(2.869)\end{array}$ & $* * *$ \\
\hline N Max. & 93,403 & 48,748 & 44,655 & 93,403 & \\
\hline
\end{tabular}

Notes: The sample consists of 38 Raumordnungsregionen ("RORs" or "cities") in the former territory of West Germany. Standard are in parentheses. The sample is divided as above and below destruction using rubble in $\mathrm{m}^{3}$ per capita as a measure of wartime 
Table 2. Descriptive Statistics, Microcensus Data

\begin{tabular}{|c|c|c|c|}
\hline & All & $\begin{array}{c}\text { Women born btw. } \\
\text { 1920-1934 } \\
(2) \\
\end{array}$ & $\begin{array}{c}\text { Women born btw. } \\
\text { 1940-1954 } \\
(3) \\
\end{array}$ \\
\hline Years of Schooling & $\begin{array}{l}10.410 \\
(1.860)\end{array}$ & $\begin{array}{l}9.995 \\
(1.566)\end{array}$ & $\begin{array}{l}10.820 \\
(2.029)\end{array}$ \\
\hline $\begin{array}{l}\text { Has Gymnasium Diploma } \\
\text { or More }\end{array}$ & $\begin{array}{c}0.050 \\
(0.218)\end{array}$ & $\begin{array}{c}0.035 \\
(0.185)\end{array}$ & $\begin{array}{c}0.064 \\
(0.245)\end{array}$ \\
\hline Technical High School Diploma & $\begin{array}{c}0.179 \\
(0.383)\end{array}$ & $\begin{array}{c}0.125 \\
(0.331)\end{array}$ & $\begin{array}{c}0.232 \\
(0.422)\end{array}$ \\
\hline Basic High School Diploma & $\begin{array}{c}0.762 \\
(0.426)\end{array}$ & $\begin{array}{c}0.832 \\
(0.373)\end{array}$ & $\begin{array}{c}0.692 \\
(0.462)\end{array}$ \\
\hline Employment & $\begin{array}{l}0.499 \\
(0.500)\end{array}$ & $\begin{array}{l}0.446 \\
(0.497)\end{array}$ & $\begin{array}{l}0.551 \\
(0.497)\end{array}$ \\
\hline Full-time Employment & $\begin{array}{l}0.472 \\
(0.499)\end{array}$ & $\begin{array}{l}0.421 \\
(0.494)\end{array}$ & $\begin{array}{l}0.524 \\
(0.499)\end{array}$ \\
\hline Part-time Employment & $\begin{array}{l}0.187 \\
(0.390)\end{array}$ & $\begin{array}{l}0.184 \\
(0.387)\end{array}$ & $\begin{array}{l}0.189 \\
(0.392)\end{array}$ \\
\hline Weekly Hours Worked & $\begin{array}{l}36.146 \\
(14.465)\end{array}$ & $\begin{array}{l}36.954 \\
(15.747)\end{array}$ & $\begin{array}{l}35.494 \\
(13.304)\end{array}$ \\
\hline Monthly Income in DM & $\begin{array}{r}1,033.496 \\
(661.467)\end{array}$ & $\begin{array}{l}997.446 \\
(703.225)\end{array}$ & $\begin{array}{r}1,063.965 \\
(622.386)\end{array}$ \\
\hline Low-Skill Occupation & $\begin{array}{c}0.143 \\
(0.350)\end{array}$ & $\begin{array}{c}0.180 \\
(0.384)\end{array}$ & $\begin{array}{c}0.107 \\
(0.384)\end{array}$ \\
\hline Medium-Skill Occupation & $\begin{array}{c}0.827 \\
(0.378)\end{array}$ & $\begin{array}{c}0.805 \\
(0.396)\end{array}$ & $\begin{array}{c}0.848 \\
(0.396)\end{array}$ \\
\hline High-Skill Occupation & $\begin{array}{c}0.029 \\
(0.169)\end{array}$ & $\begin{array}{c}0.015 \\
(0.122)\end{array}$ & $\begin{array}{c}0.045 \\
(0.122)\end{array}$ \\
\hline Female-Concentrated Occupation & $\begin{array}{c}0.903 \\
(0.298)\end{array}$ & $\begin{array}{c}0.902 \\
(0.298)\end{array}$ & $\begin{array}{c}0.904 \\
(0.298)\end{array}$ \\
\hline Female-Dominated Occupation & $\begin{array}{l}0.884 \\
(0.320)\end{array}$ & $\begin{array}{l}0.884 \\
(0.320)\end{array}$ & $\begin{array}{l}0.884 \\
(0.320)\end{array}$ \\
\hline Married & $\begin{array}{l}0.806 \\
(0.395)\end{array}$ & $\begin{array}{l}0.793 \\
(0.405)\end{array}$ & $\begin{array}{l}0.820 \\
(0.384)\end{array}$ \\
\hline Number of Kids & $\begin{array}{l}1.222 \\
(1.189)\end{array}$ & $\begin{array}{l}1.068 \\
(1.246)\end{array}$ & $\begin{array}{l}1.376 \\
(1.108)\end{array}$ \\
\hline $\begin{array}{l}\text { Monthly Income of Household } \\
\text { Head }\end{array}$ & $\begin{array}{l}1,788.987 \\
(1,044.920)\end{array}$ & $\begin{array}{l}1,731.237 \\
(1,105.831)\end{array}$ & $\begin{array}{r}1,845.725 \\
(978.101)\end{array}$ \\
\hline Move from East after WWII & $\begin{array}{l}0.009 \\
(0.097)\end{array}$ & $\begin{array}{l}0.011 \\
(0.103)\end{array}$ & $\begin{array}{l}0.008 \\
(0.090)\end{array}$ \\
\hline Rural & $\begin{array}{l}0.565 \\
(0.496)\end{array}$ & $\begin{array}{l}0.563 \\
(0.496)\end{array}$ & $\begin{array}{l}0.566 \\
(0.496)\end{array}$ \\
\hline $\mathrm{N} \max$. & 93,403 & 46,673 & 46,730 \\
\hline
\end{tabular}

Notes: Data are from the 1978 German Microcensus. The sample consists of individuals born between 1920 and 1954. Individuals born between 1935 and 1939 are dropped from the analysis since their exposure to the WWII destruction is not as clear. Standard deviations are presented in parentheses. 
Table 3. Effect of Postwar Reconstruction on Female Employment

\begin{tabular}{|c|c|c|c|}
\hline & $(1)$ & $(2)$ & (3) \\
\hline Rubble per Cap.X Born btw.1920-1934 & $\begin{array}{c}-0.0017 * * * \\
(0.0006)\end{array}$ & $\begin{array}{c}-0.0018 * * * \\
(0.0006)\end{array}$ & $\begin{array}{c}-0.0019 * * * \\
(0.0006)\end{array}$ \\
\hline Years of Schooling & & $\begin{array}{c}0.0361 * * * \\
(0.0010)\end{array}$ & $\begin{array}{c}0.0574 * * * \\
(0.0013)\end{array}$ \\
\hline Married & & $\begin{array}{c}-0.2494 * * * \\
(0.0045)\end{array}$ & $\begin{array}{c}-0.2414 * * * \\
(0.0045)\end{array}$ \\
\hline Number of Kids & & $\begin{array}{c}-0.0749 * * * \\
(0.0025)\end{array}$ & $\begin{array}{c}-0.0733 * * * \\
(0.0026)\end{array}$ \\
\hline Log Wage of Household Head & & & $\begin{array}{c}0.0099 * * * \\
(0.0009)\end{array}$ \\
\hline Years of Schooling of Household Head & & & $\begin{array}{c}-0.0301 * * * \\
(0.0011)\end{array}$ \\
\hline $\begin{array}{l}\mathrm{R}^{2} \\
\mathrm{~N}\end{array}$ & $\begin{array}{l}0.0514 \\
90,663\end{array}$ & $\begin{array}{l}0.1482 \\
87,050\end{array}$ & $\begin{array}{l}0.1596 \\
85,976\end{array}$ \\
\hline
\end{tabular}

Notes: Standard errors clustered by cities are shown in parentheses. Asterisks denote significance levels $(*=.10, * *=.05, * * *=.01)$. The control group is individuals born between 1940 and 1954. Each column is from a separate regression which controls for city and birth year fixed effects and a rural dummy. In column (3), we also control for whether an individual moved from East Germany after WWII. 
Table 4. Effect of Postwar Reconstruction on Female Employment: IV Results

(1)

(2)

(3)

Second-Stage

Rubble per Cap. X Born btw.1920-1934

$-0.0036 * * *$

(0.0013)

$-0.0055^{* * * *}$

$-0.0057 * * *$

(0.0013)

(0.0013)

Years of Schooling

$\begin{array}{cc}0.0360 * * * & 0.0575 * * * \\ (0.0010) & (0.0013)\end{array}$

Married

$-0.2491 * * * \quad-0.2410 * * *$

(0.0045)

(0.0045)

Number of Kids

$-0.0750 * * * \quad-0.0735 * * *$

(0.0025) (0.0026)

Log Wage of Household Head

$0.0100 * * *$

(0.0009)

Years of Schooling of Household Head

$-0.0302 * * *$

(0.0011)

\section{First-Stage}

\section{Dependent Variable: Rubble per Capita X Born btw. 1920 and 1934}

\begin{tabular}{lccc} 
Distance to London (in miles) X Born btw.1920-1934 & $-0.0338 * * *$ & $-0.0341 * * *$ & $-0.0341 * * *$ \\
& $(0.0002)$ & $(0.0002)$ & $(0.0002)$ \\
F-Statistic for first-stage & 9643.72 & 9105.82 & 8748.55 \\
& & & 0.8813 \\
$\mathrm{R}^{2}$ & 0.8813 & 0.8813 & 85,976 \\
$\mathrm{~N}$ & 90,663 & 87,050 & \\
\hline \hline
\end{tabular}

Notes: Standard errors clustered by cities are shown in parentheses. Asterisks denote significance levels $(*=.10, * *=.05, * * *=.01)$. The control group is individuals born between 1940 and 1954. Each column is from a separate regression which controls for city and birth year fixed effects and a rural dummy. In column (3), we also control for whether an individual moved from East Germany after WWII. The identifying instrument for city's war destruction is city's distance to London. 
Table 5. Effect of Postwar Reconstruction on Female Full-time Employment

\begin{tabular}{|c|c|c|c|c|c|c|}
\hline & \multicolumn{3}{|c|}{ Difference-in-Difference } & \multicolumn{3}{|c|}{ Instrumental Variable } \\
\hline & $(1)$ & $(2)$ & $(3)$ & $(4)$ & $(5)$ & $(6)$ \\
\hline Rubble per Cap. X Born btw.1920-1934 & $\begin{array}{c}-0.0014 * * \\
(0.0006)\end{array}$ & $\begin{array}{c}-0.0015 * * * \\
(0.0006)\end{array}$ & $\begin{array}{c}-0.0017 * * * \\
(0.0006)\end{array}$ & $\begin{array}{c}-0.0026^{* *} \\
(0.0013)\end{array}$ & $\begin{array}{c}-0.0046^{* * *} \\
(0.0013)\end{array}$ & $\begin{array}{c}-0.0049 * * * \\
(0.0013)\end{array}$ \\
\hline Years of Schooling & & $\begin{array}{c}0.0361 * * * \\
(0.0011)\end{array}$ & $\begin{array}{c}0.0570 * * * \\
(0.0012)\end{array}$ & & $\begin{array}{c}0.0361 * * * \\
(0.0011)\end{array}$ & $\begin{array}{c}0.0570 * * * \\
(0.0012)\end{array}$ \\
\hline Married & & $\begin{array}{c}-0.2645^{* * *} * \\
(0.0046)\end{array}$ & $\begin{array}{c}-0.2570 * * * \\
(0.0046)\end{array}$ & & $\begin{array}{c}-0.2642 * * * \\
(0.0046)\end{array}$ & $\begin{array}{c}-0.2567 * * * \\
(0.0046)\end{array}$ \\
\hline Number of Kids & & $\begin{array}{c}-0.0778 * * * \\
(0.0025)\end{array}$ & $\begin{array}{c}-0.0762 * * * \\
(0.0026)\end{array}$ & & $\begin{array}{c}-0.0779 * * * \\
(0.0025)\end{array}$ & $\begin{array}{c}-0.0763 * * * \\
(0.0026)\end{array}$ \\
\hline Log Wage of Household Head & & & $\begin{array}{c}0.0100 * * * \\
(0.0009)\end{array}$ & & & $\begin{array}{c}0.0100 * * * \\
(0.0009)\end{array}$ \\
\hline Years of Schooling of Household Head & & & $\begin{array}{c}-0.0296 * * * \\
(0.0011)\end{array}$ & & & $\begin{array}{c}-0.0297 * * \\
(0.0011)\end{array}$ \\
\hline $\begin{array}{l}\mathrm{R}^{2} \\
\mathrm{~N}\end{array}$ & $\begin{array}{l}0.0523 \\
90,806\end{array}$ & $\begin{array}{l}0.1572 \\
87,178\end{array}$ & $\begin{array}{l}0.1682 \\
86,101\end{array}$ & $\begin{array}{l}0.0522 \\
90,806\end{array}$ & $\begin{array}{l}0.1569 \\
87,178\end{array}$ & $\begin{array}{l}0.1679 \\
86,101\end{array}$ \\
\hline
\end{tabular}

Notes: Standard errors clustered by cities are shown in parentheses. Asterisks denote significance levels $(*=.10, * *=.05, * * *=.01)$. The control group is individuals born between 1940 and 1954. Each column is from a separate regression which controls for city and birth year fixed effects and a rural dummy. In columns (3) and (6), we also control for whether an individual moved from East Germany after WWII. The identifying instrument for city's war destruction is city's distance to London. 
Table 6. Effect of Postwar Reconstruction on Female Part-time Employment

\begin{tabular}{|c|c|c|c|c|c|c|}
\hline & \multicolumn{3}{|c|}{ Difference-in-Difference } & \multicolumn{3}{|c|}{ Instrumental Variable } \\
\hline & (1) & (2) & (3) & (4) & $(5)$ & $(6)$ \\
\hline Rubble per Cap. X Born btw.1920-1934 & $\begin{array}{c}0.0003 \\
(0.0006)\end{array}$ & $\begin{array}{c}0.0003 \\
(0.0006)\end{array}$ & $\begin{array}{c}0.0004 \\
(0.0006)\end{array}$ & $\begin{array}{c}0.0013 \\
(0.0012)\end{array}$ & $\begin{array}{c}0.0019 \\
(0.0013)\end{array}$ & $\begin{array}{c}0.0021 \\
(0.0013)\end{array}$ \\
\hline Years of Schooling & & $\begin{array}{c}0.0024 * * \\
(0.0010)\end{array}$ & $\begin{array}{c}-0.0030 * * \\
(0.0015)\end{array}$ & & $\begin{array}{c}0.0024 * * \\
(0.0010)\end{array}$ & $\begin{array}{c}-0.0031 * * \\
(0.0015)\end{array}$ \\
\hline Married & & $\begin{array}{c}0.1385^{* * *} \\
(0.0038)\end{array}$ & $\begin{array}{c}0.1325 * * * \\
(0.0039)\end{array}$ & & $\begin{array}{c}0.1384 * * * \\
(0.0038)\end{array}$ & $\begin{array}{c}0.1324 * * * \\
(0.0039)\end{array}$ \\
\hline Number of Kids & & $\begin{array}{c}0.0487 * * * \\
(0.0024)\end{array}$ & $\begin{array}{c}0.0521 * * * \\
(0.0024)\end{array}$ & & $\begin{array}{c}0.0488 * * * \\
(0.0024)\end{array}$ & $\begin{array}{c}0.0521 * * * \\
(0.0024)\end{array}$ \\
\hline Log Wage of Household Head & & & $\begin{array}{c}0.0089 \text { *** } \\
(0.0008)\end{array}$ & & & $\begin{array}{c}0.0089 * * * \\
(0.0008)\end{array}$ \\
\hline Years of Schooling of Household Head & & & $\begin{array}{c}0.0065^{* * * *} \\
(0.0015)\end{array}$ & & & $\begin{array}{c}0.0066^{* * *} \\
(0.0015)\end{array}$ \\
\hline $\begin{array}{l}\mathrm{R}^{2} \\
\mathrm{~N}\end{array}$ & $\begin{array}{l}0.0237 \\
45,551\end{array}$ & $\begin{array}{l}0.0698 \\
44,947\end{array}$ & $\begin{array}{l}0.0754 \\
44,276\end{array}$ & $\begin{array}{l}0.0236 \\
45,551\end{array}$ & $\begin{array}{l}0.0697 \\
44,947\end{array}$ & $\begin{array}{l}0.0752 \\
44,276\end{array}$ \\
\hline
\end{tabular}

Notes: Standard errors clustered by cities are shown in parentheses. Asterisks denote significance levels $(*=.10, * *=.05, * * *=.01)$. Female is coded as working part-time if she works less than 20 hours per week. The control group is individuals born between 1940 and 1954. Each column is from a separate regression which controls for city and birth year fixed effects and a rural dummy. In columns (3) and (6), we also control for whether an individual moved from East Germany after WWII. The identifying instrument for city's wartime destruction is city's distance to London. 
Table 7. Effect of Postwar Reconstruction on Weekly Hours Worked

\begin{tabular}{|c|c|c|c|c|c|c|}
\hline & \multicolumn{3}{|c|}{ Difference-in-Difference } & \multicolumn{3}{|c|}{ Instrumental Variable } \\
\hline & $(1)$ & $(2)$ & (3) & $(4)$ & (5) & $(6)$ \\
\hline Rubble per Cap. X Born btw.1920-1934 & $\begin{array}{r}-0.0643 * * * \\
(0.0248)\end{array}$ & $\begin{array}{c}-0.0703 * * * \\
(0.0250)\end{array}$ & $\begin{array}{c}-0.0726^{* * *} * \\
(0.0244)\end{array}$ & $\begin{array}{c}-0.1755^{* * *} * \\
(0.0503)\end{array}$ & $\begin{array}{c}-0.2366 * * * \\
(0.0571)\end{array}$ & $\begin{array}{c}-0.2301 * * * \\
(0.0560)\end{array}$ \\
\hline Years of Schooling & & $\begin{array}{c}-0.1279 * * * \\
(0.0347)\end{array}$ & $\begin{array}{c}0.0338 \\
(0.0515)\end{array}$ & & $\begin{array}{c}-0.1289 * * * \\
(0.0347)\end{array}$ & $\begin{array}{c}0.0378 \\
(0.0515)\end{array}$ \\
\hline Married & & $\begin{array}{c}-4.0604 * * * \\
(0.1440)\end{array}$ & $\begin{array}{c}-3.7489 * * * \\
(0.1487)\end{array}$ & & $\begin{array}{c}-4.0535 * * * \\
(0.1443)\end{array}$ & $\begin{array}{c}-3.7378 * * * \\
(0.1490)\end{array}$ \\
\hline Number of Kids & & $\begin{array}{c}-0.3763 * * * \\
(0.1028)\end{array}$ & $\begin{array}{c}-0.6749 * * * \\
(0.0999)\end{array}$ & & $\begin{array}{c}-0.3818 * * * \\
(0.1028)\end{array}$ & $\begin{array}{c}-0.6807 * * * \\
(0.0999)\end{array}$ \\
\hline Log Wage of Household Head & & & $\begin{array}{c}-0.8870 * * * \\
(0.0380)\end{array}$ & & & $\begin{array}{c}-0.8864 * * * \\
(0.0380)\end{array}$ \\
\hline Years of Schooling of Household Head & & & $\begin{array}{c}-0.1296 * * * \\
(0.0477)\end{array}$ & & & $\begin{array}{c}-0.1365 * * * \\
(0.0477)\end{array}$ \\
\hline $\begin{array}{l}\mathrm{R}^{2} \\
\mathrm{~N}\end{array}$ & $\begin{array}{c}0.0255 \\
45551\end{array}$ & $\begin{array}{l}0.0426 \\
44,947\end{array}$ & $\begin{array}{l}0.0728 \\
44,276\end{array}$ & $\begin{array}{c}0.025 \\
45,551\end{array}$ & $\begin{array}{l}0.0413 \\
44,947\end{array}$ & $\begin{array}{l}0.0718 \\
44,276\end{array}$ \\
\hline
\end{tabular}

Notes: Standard errors clustered by cities are shown in parentheses. Asterisks denote significance levels $(*=.10, * *=.05, * * *=.01)$. The control group is individuals born between 1940 and 1954. Each column is from a separate regression which controls for city and birth year fixed effects and a rural dummy. In columns (3) and (6), we also control for whether an individual moved from East Germany after WWII. The identifying instrument for city's war destruction is city's distance to London. 
Table 8. Labor Supply and Labor Demand Factors

\begin{tabular}{|c|c|c|c|c|}
\hline & $(1)$ & $\begin{array}{c}\begin{array}{c}\text { Full-time } \\
\text { Employment }\end{array} \\
(2)\end{array}$ & $\begin{array}{c}\begin{array}{c}\text { Part-time } \\
\text { Employment }\end{array} \\
(3)\end{array}$ & $\begin{array}{c}\begin{array}{c}\text { Weekly Hours } \\
\text { Worked }\end{array} \\
(4)\end{array}$ \\
\hline Rubble per Cap.X Born btw.1920-1934 & $\begin{array}{c}-0.0023 * * * \\
(0.0008)\end{array}$ & $\begin{array}{c}-0.0020^{* *} \\
(0.0008)\end{array}$ & $\begin{array}{c}0.0029 * * * \\
(0.0010)\end{array}$ & $\begin{array}{c}-0.1198 * * * \\
(0.0381)\end{array}$ \\
\hline Female/Male Ratio X Born btw.1920-1934 & $\begin{array}{c}-0.0016 \\
(0.0010)\end{array}$ & $\begin{array}{c}-0.0015 \\
(0.0010)\end{array}$ & $\begin{array}{c}0.0008 \\
(0.0011)\end{array}$ & $\begin{array}{c}-0.0491 \\
(0.0413)\end{array}$ \\
\hline Change in Female Share in Industry X Born btw.1920-1934 & $\begin{array}{l}-0.0027^{*} \\
(0.0016)\end{array}$ & $\begin{array}{c}-0.0023 \\
(0.0015)\end{array}$ & $\begin{array}{c}0.0016 \\
(0.0017)\end{array}$ & $\begin{array}{c}-0.1689^{* *} \\
(0.0666)\end{array}$ \\
\hline Change in Female Share in Construction X Born btw.1920-1934 & $\begin{array}{c}0.0025 \\
(0.0031)\end{array}$ & $\begin{array}{c}0.0025 \\
(0.0032)\end{array}$ & $\begin{array}{c}0.0026 \\
(0.0037)\end{array}$ & $\begin{array}{c}-0.0142 \\
(0.1356)\end{array}$ \\
\hline Change in Female Share in Service Sector X Born btw.1920-1934 & $\begin{array}{c}-0.0002 \\
(0.0071)\end{array}$ & $\begin{array}{c}0.0004 \\
(0.0070)\end{array}$ & $\begin{array}{c}-0.0019 \\
(0.0079)\end{array}$ & $\begin{array}{c}-0.3420 \\
(0.2974)\end{array}$ \\
\hline Change in Female Share in Public Sector X Born btw.1920-1934 & $\begin{array}{c}-0.0003 \\
(0.0040)\end{array}$ & $\begin{array}{c}-0.0009 \\
(0.0040)\end{array}$ & $\begin{array}{c}0.0045 \\
(0.0046)\end{array}$ & $\begin{array}{c}-0.0670 \\
(0.1742)\end{array}$ \\
\hline Per Capita War Relief Payments X Born btw.1920-1934 & $\begin{array}{c}-0.0041 \text { *** } \\
(0.0013)\end{array}$ & $\begin{array}{c}-0.0035^{* * *} * \\
(0.0013)\end{array}$ & $\begin{array}{c}0.0038 * * * \\
(0.0014)\end{array}$ & $\begin{array}{c}-0.1347 * * * \\
(0.0517)\end{array}$ \\
\hline Amount of Savings Loss during WWII X Born btw.1920-1934 & $\begin{array}{c}0.0022 * * * \\
(0.0008)\end{array}$ & $\begin{array}{c}0.0023^{* * *} * \\
(0.0008)\end{array}$ & $\begin{array}{c}0.0009 \\
(0.0009)\end{array}$ & $\begin{array}{l}-0.0130 \\
(0.0332)\end{array}$ \\
\hline Migrant Share X Born btw.1920-1934 & $\begin{array}{c}-0.0014 \\
(0.0016)\end{array}$ & $\begin{array}{c}-0.0018 \\
(0.0016)\end{array}$ & $\begin{array}{l}-0.0022 \\
(0.0019)\end{array}$ & $\begin{array}{c}0.0948 \\
(0.0707)\end{array}$ \\
\hline Refugee Share X Born btw.1920-1934 & $\begin{array}{c}0.0039 * * * \\
(0.0012)\end{array}$ & $\begin{array}{c}0.0033^{* * *} \\
(0.0012)\end{array}$ & $\begin{array}{c}-0.0022 \\
(0.0014)\end{array}$ & $\begin{array}{c}0.1137 * * \\
(0.0487)\end{array}$ \\
\hline $\begin{array}{l}\mathrm{R}^{2} \\
\mathrm{~N}\end{array}$ & $\begin{array}{l}0.1570 \\
75,789 \\
\end{array}$ & $\begin{array}{l}0.1659 \\
75,908 \\
\end{array}$ & $\begin{array}{l}0.0755 \\
38,777 \\
\end{array}$ & $\begin{array}{l}0.0691 \\
38,777 \\
\end{array}$ \\
\hline
\end{tabular}

Notes: Standard errors clustered by cities are shown in parentheses. Asterisks denote significance levels $(*=.10, * *=.05, * * *=.01)$. The control group is individuals born between 1940 and 1954. Each column is from a separate regression which controls for city and birth year fixed effects and a rural dummy. Other control in each regression are years of schooling, married dummy, number of kids, an 
Table 9. Effect of Postwar Reconstruction on Female Occupational Choice by Skill Level

\begin{tabular}{|c|c|c|c|c|c|c|}
\hline & \multicolumn{3}{|c|}{ Difference-in-Difference } & \multicolumn{3}{|c|}{ Instrumental Variable } \\
\hline & $\frac{\text { Low-Skill }}{(1)}$ & $\frac{\text { Medium-Skill }}{(2)}$ & $\frac{\text { High-Skill }}{(3)}$ & $\frac{\text { Low-Skill }}{(4)}$ & $\frac{\text { Medium-Skill }}{(5)}$ & $\frac{\text { High-Skill }}{(6)}$ \\
\hline Rubble per Cap.X Born btw.1920-1934 & $\begin{array}{c}-0.0014 * * * \\
(0.0005)\end{array}$ & $\begin{array}{c}0.0016^{* * * *} \\
(0.0005)\end{array}$ & $\begin{array}{l}-0.0002 \\
(0.0002)\end{array}$ & $\begin{array}{c}-0.0060 * * * \\
(0.0011)\end{array}$ & $\begin{array}{c}0.0063 * * * \\
(0.0012)\end{array}$ & $\begin{array}{l}-0.0003 \\
(0.0003)\end{array}$ \\
\hline Years of Schooling & $\begin{array}{c}-0.0206 * * * \\
(0.0007)\end{array}$ & $\begin{array}{c}-0.0445 * * * \\
(0.0014)\end{array}$ & $\begin{array}{c}0.0651 * * * \\
(0.0011)\end{array}$ & $\begin{array}{c}-0.0206 * * * \\
(0.0007)\end{array}$ & $\begin{array}{c}-0.0445 * * * \\
(0.0014)\end{array}$ & $\begin{array}{c}0.0651 * * * \\
(0.0011)\end{array}$ \\
\hline Married & $\begin{array}{c}-0.0290 * * * \\
(0.0038)\end{array}$ & $\begin{array}{c}0.0335 * * * \\
(0.0042)\end{array}$ & $\begin{array}{c}-0.00444 * * * \\
(0.0016)\end{array}$ & $\begin{array}{c}-0.0286 * * * \\
(0.0038)\end{array}$ & $\begin{array}{c}0.0330 * * * \\
(0.0042)\end{array}$ & $\begin{array}{c}-0.0044 * * * \\
(0.0016)\end{array}$ \\
\hline Number of Kids & $\begin{array}{c}0.0061 * * * \\
(0.0014)\end{array}$ & $\begin{array}{c}-0.0063 * * * \\
(0.0015)\end{array}$ & $\begin{array}{c}0.0002 \\
(0.0005)\end{array}$ & $\begin{array}{c}0.0060 * * * \\
(0.0014)\end{array}$ & $\begin{array}{c}-0.0061 * * * \\
(0.0015)\end{array}$ & $\begin{array}{c}0.0002 \\
(0.0004)\end{array}$ \\
\hline Log Wage of Household Head & $\begin{array}{c}-0.0104 * * * \\
(0.0007)\end{array}$ & $\begin{array}{c}0.0113 * * * \\
(0.0007)\end{array}$ & $\begin{array}{c}-0.0009 * * * \\
(0.0002)\end{array}$ & $\begin{array}{c}-0.0103 * * * \\
(0.0007)\end{array}$ & $\begin{array}{c}0.0112 * * * \\
(0.0007)\end{array}$ & $\begin{array}{c}-0.0009 * * * \\
(0.0002)\end{array}$ \\
\hline Years of Schooling of Household Head & $\begin{array}{c}-0.0166 * * * \\
(0.0006)\end{array}$ & $\begin{array}{c}0.0188 * * * \\
(0.0008)\end{array}$ & $\begin{array}{c}-0.0022 * * * \\
(0.0005)\end{array}$ & $\begin{array}{c}-0.0167 * * * \\
(0.0006)\end{array}$ & $\begin{array}{c}0.0189 * * * \\
(0.0008)\end{array}$ & $\begin{array}{c}-0.0023 * * * \\
(0.0005)\end{array}$ \\
\hline $\begin{array}{l}\mathrm{R}^{2} \\
\mathrm{~N}\end{array}$ & $\begin{array}{l}0.1097 \\
86,101\end{array}$ & $\begin{array}{l}0.0805 \\
86,101\end{array}$ & $\begin{array}{l}0.4416 \\
86,101\end{array}$ & $\begin{array}{l}0.1083 \\
86,101\end{array}$ & $\begin{array}{l}0.0792 \\
86,101\end{array}$ & $\begin{array}{l}0.4416 \\
86,101\end{array}$ \\
\hline
\end{tabular}

Notes: Standard errors clustered by cities are shown in parentheses. Asterisks denote significance levels $(*=.10, * *=.05$, ***=.01). The control group is individuals born between 1940 and 1954. Each column is from a separate regression which controls for city and birth year fixed effects, a rural dummy and whether an individual moved from East Germany after WWII. The identifying instrument for city's war destruction is city's distance to London. Occupation i defined as "Low Skill" if the average years of schooling of workers in this occupation is less than 10 years. "Medium-Skill" are occupations where the average years of schooling of workers are between 10 and 14 years. Occupation is defined as "High-Skill" if workers in this occupation have 15 years of schooling or more on average. 
Table 10. Effect of Postwar Reconstruction on Female Occupational Choice

\begin{tabular}{|c|c|c|c|c|}
\hline & \multicolumn{2}{|c|}{ Difference-in-Difference } & \multicolumn{2}{|c|}{ Instrumental Variable } \\
\hline & $\frac{\text { Female-Concentrated }}{(1)}$ & $\frac{\text { Female-Dominated }}{(2)}$ & $\frac{\text { Female-Concentrated }}{(3)}$ & $\frac{\text { Female-Dominated }}{(4)}$ \\
\hline Rubble per Cap. X Born btw.1920-1934 & $\begin{array}{c}0.0010 * * * \\
(0.0003)\end{array}$ & $\begin{array}{c}0.0010 * * * \\
(0.0004)\end{array}$ & $\begin{array}{c}0.0018 * * * \\
(0.0008)\end{array}$ & $\begin{array}{c}0.0017 * * \\
(0.0009)\end{array}$ \\
\hline Years of Schooling & $\begin{array}{c}-0.0115 * * * \\
(0.0009)\end{array}$ & $\begin{array}{c}-0.0103 * * * \\
(0.0010)\end{array}$ & $\begin{array}{c}-0.0115^{* * *} \\
(0.0009)\end{array}$ & $\begin{array}{l}-0.0103 * * * \\
(0.0010)\end{array}$ \\
\hline Married & $\begin{array}{c}0.0632 * * * \\
(0.0036)\end{array}$ & $\begin{array}{c}0.0809 * * * \\
(0.0041)\end{array}$ & $\begin{array}{c}0.0631 * * * \\
(0.0036)\end{array}$ & $\begin{array}{c}0.0808 * * * \\
(0.0041)\end{array}$ \\
\hline Number of Kids & $\begin{array}{c}0.0103 * * * \\
(0.0011)\end{array}$ & $\begin{array}{c}0.0202 * * * \\
(0.0013)\end{array}$ & $\begin{array}{c}0.0103 * * * \\
(0.0011)\end{array}$ & $\begin{array}{c}0.0202 * * * \\
(0.0013)\end{array}$ \\
\hline Log Wage of Household Head & $\begin{array}{c}-0.0002 \\
(0.0004)\end{array}$ & $\begin{array}{l}0.0010 * * \\
(0.0005)\end{array}$ & $\begin{array}{c}-0.0002 \\
(0.0004)\end{array}$ & $\begin{array}{l}0.0010^{* *} \\
(0.0005)\end{array}$ \\
\hline Years of Schooling of Household Head & $\begin{array}{c}0.0048 * * * \\
(0.0006)\end{array}$ & $\begin{array}{c}0.0050 * * * \\
(0.0007)\end{array}$ & $\begin{array}{c}0.0048 * * * \\
(0.0006)\end{array}$ & $\begin{array}{c}0.0050 * * * \\
(0.0007)\end{array}$ \\
\hline $\begin{array}{l}\mathrm{R}^{2} \\
\mathrm{~N}\end{array}$ & $\begin{array}{l}0.0225 \\
86,101\end{array}$ & $\begin{array}{l}0.0286 \\
86,101\end{array}$ & $\begin{array}{l}0.0224 \\
86,101\end{array}$ & $\begin{array}{l}0.0285 \\
86,101\end{array}$ \\
\hline
\end{tabular}

Notes: Standard errors clustered by cities are shown in parentheses. Asterisks denote significance levels $(*=.10, * *=.05, * * *=.01)$. The control group is individuals born between 1940 and 1954. Each column is from a separate regression which controls for city and birth year fixed effects, a rural dummy and whether an individual moved from East Germany after WWII. The identifying instrument for city's war destruction is city's distance to London. Occupation is defined as "Female-concentrated" if females constitute more than $40 \%$ of employees in this occupation. "Female-dominated" are occupations where the majority of the employees in this occupation are females. 
Table 11. Labor Supply and Labor Demand Factors

\begin{tabular}{|c|c|c|c|c|c|}
\hline & $\begin{array}{c}\begin{array}{c}\text { Low } \\
\text { Skilled }\end{array} \\
(1) \\
\end{array}$ & $\begin{array}{c}\begin{array}{c}\text { Medium } \\
\text { Skilled }\end{array} \\
(2) \\
\end{array}$ & $\begin{array}{c}\begin{array}{c}\text { High } \\
\text { Skilled }\end{array} \\
(3)\end{array}$ & $\begin{array}{c}\begin{array}{c}\text { Female } \\
\text { Concentrated }\end{array} \\
(4) \\
\end{array}$ & $\begin{array}{c}\begin{array}{c}\text { Female } \\
\text { Dominated }\end{array} \\
(5) \\
\end{array}$ \\
\hline Rubble per Cap.X Born btw.1920-1934 & $\begin{array}{c}-0.0014 * * \\
(0.0006)\end{array}$ & $\begin{array}{c}0.0015 * * \\
(0.0007)\end{array}$ & $\begin{array}{l}-0.0001 \\
(0.0002)\end{array}$ & $\begin{array}{c}0.0017 * * * \\
(0.0005)\end{array}$ & $\begin{array}{c}0.0018 * * * \\
(0.0006)\end{array}$ \\
\hline Female/Male Ratio X Born btw.1920-1934 & $\begin{array}{l}-0.0009 \\
(0.0008)\end{array}$ & $\begin{array}{l}0.0010 \\
(0.0008)\end{array}$ & $\begin{array}{l}-0.0001 \\
(0.0003)\end{array}$ & $\begin{array}{c}0.0003 \\
(0.0006)\end{array}$ & $\begin{array}{l}-0.0003 \\
(0.0008)\end{array}$ \\
\hline Change in Female Share in Industry X Born btw.1920-1934 & $\begin{array}{c}-0.0028 * * \\
(0.0012)\end{array}$ & $\begin{array}{c}0.0031 * * \\
(0.0013)\end{array}$ & $\begin{array}{l}-0.0003 \\
(0.0004)\end{array}$ & $\begin{array}{c}0.0021^{* *} \\
(0.0009)\end{array}$ & $\begin{array}{c}-0.0015 * * * \\
\quad(0.0004)\end{array}$ \\
\hline Change in Female Share in Construction X Born btw.1920-1934 & $\begin{array}{c}-0.0004 \\
(0.0023)\end{array}$ & $\begin{array}{l}-0.0004 \\
(0.0025)\end{array}$ & $\begin{array}{c}0.0008 \\
(0.0008)\end{array}$ & $\begin{array}{l}-0.0006 \\
(0.0019)\end{array}$ & $\begin{array}{l}-0.0006 \\
(0.0028)\end{array}$ \\
\hline Change in Female Share in Service Sector X Born btw.1920-1934 & $\begin{array}{c}-0.0115 * * \\
(0.0058)\end{array}$ & $\begin{array}{l}0.0107 * \\
(0.0062)\end{array}$ & $\begin{array}{c}0.0008 \\
(0.0018)\end{array}$ & $\begin{array}{c}0.0010 \\
(0.0041)\end{array}$ & $\begin{array}{l}-0.0019 \\
(0.0028)\end{array}$ \\
\hline Change in Female Share in Public Sector X Born btw.1920-1934 & $\begin{array}{c}0.0015 \\
(0.0031)\end{array}$ & $\begin{array}{l}-0.0004 \\
(0.0034)\end{array}$ & $\begin{array}{l}-0.0011 \\
(0.0010)\end{array}$ & $\begin{array}{c}0.0021 \\
(0.0024)\end{array}$ & $\begin{array}{c}0.0001 \\
(0.0012)\end{array}$ \\
\hline Per Capita War Relief Payments X Born btw.1920-1934 & $\begin{array}{c}-0.0019 * * \\
(0.0009)\end{array}$ & $\begin{array}{l}0.0017 * \\
(0.0010)\end{array}$ & $\begin{array}{c}0.0002 \\
(0.0004)\end{array}$ & $\begin{array}{c}0.0024 * * * \\
(0.0008)\end{array}$ & $\begin{array}{c}0.0038 * * * \\
(0.0011)\end{array}$ \\
\hline Per Capita Savings Loss during WWII X Born btw.1920-1934 & $\begin{array}{c}0.0007 \\
(0.0006)\end{array}$ & $\begin{array}{l}-0.0005 \\
(0.0006)\end{array}$ & $\begin{array}{l}-0.0002 \\
(0.0002)\end{array}$ & $\begin{array}{l}-0.0009 * \\
(0.0005)\end{array}$ & $\begin{array}{l}-0.0012 \\
(0.0005)\end{array}$ \\
\hline Migrant Share X Born btw.1920-1934 & $\begin{array}{c}0.0003 \\
(0.0012)\end{array}$ & $\begin{array}{l}-0.0008 \\
(0.0013)\end{array}$ & $\begin{array}{c}0.0004 \\
(0.0004)\end{array}$ & $\begin{array}{c}0.0003 \\
(0.0010)\end{array}$ & $\begin{array}{c}0.0016 \\
(0.0011)\end{array}$ \\
\hline Refugee Share X Born btw.1920-1934 & $\begin{array}{c}0.0039 * * * \\
(0.0010)\end{array}$ & $\begin{array}{c}-0.0037 * * * \\
(0.0011)\end{array}$ & $\begin{array}{l}-0.0002 \\
(0.0003)\end{array}$ & $\begin{array}{l}-0.0012 \\
(0.0008)\end{array}$ & $\begin{array}{c}-0.0022 * * \\
(0.0010)\end{array}$ \\
\hline $\mathrm{R}^{2}$ & 0.1024 & 0.0751 & 0.4419 & 0.0220 & 0.0283 \\
\hline $\mathrm{N}$ & 75,908 & 75,908 & 75,908 & 75,908 & 75,908 \\
\hline
\end{tabular}

Notes: Standard errors clustered by cities are shown in parentheses. Asterisks denote significance levels $(*=.10, * *=.05, * * *=.01)$. The control group is individuals born between 1940 and 1954. Each column is from a separate regression which controls for city and birth year fixed effects and a rural dummy. Other control in each regression are years of schooling, married dummy, number of kids, an indicator of whether an 
Appendix Table 1. Effect of Postwar Reconstruction on Logarithm of Monthly Income

\begin{tabular}{|c|c|c|c|c|c|c|}
\hline & \multicolumn{3}{|c|}{ Difference-in-Difference } & \multicolumn{3}{|c|}{ Instrumental Variable } \\
\hline & (1) & (2) & (3) & $(4)$ & (5) & (6) \\
\hline Rubble per Cap.X Born btw.1920-1934 & $\begin{array}{c}0.0001 \\
(0.0010)\end{array}$ & $\begin{array}{c}0.0005 \\
(0.0009)\end{array}$ & $\begin{array}{c}0.0007 \\
(0.0009)\end{array}$ & $\begin{array}{c}0.0004 \\
(0.0021)\end{array}$ & $\begin{array}{l}-0.0021 \\
(0.0020)\end{array}$ & $\begin{array}{l}-0.0022 \\
(0.0020)\end{array}$ \\
\hline Years of Schooling & & $\begin{array}{c}0.0917 * * * \\
(0.0019)\end{array}$ & $\begin{array}{c}0.0868 * * * \\
(0.0024)\end{array}$ & & $\begin{array}{c}0.0916 * * * \\
(0.0019)\end{array}$ & $\begin{array}{c}0.0869 * * * \\
(0.0024)\end{array}$ \\
\hline Married & & $\begin{array}{c}-0.2926 * * * \\
(0.0067)\end{array}$ & $\begin{array}{c}-0.3226^{* * *} * \\
(0.0069)\end{array}$ & & $\begin{array}{c}-0.2924 * * * \\
(0.0067)\end{array}$ & $\begin{array}{c}-0.3223^{* * *} * \\
(0.0069)\end{array}$ \\
\hline Number of Kids & & $\begin{array}{c}-0.1126 * * * \\
(0.0038)\end{array}$ & $\begin{array}{c}-0.1068 * * * \\
(0.0038)\end{array}$ & & $\begin{array}{c}-0.1126^{* * * *} \\
(0.0038)\end{array}$ & $\begin{array}{c}-0.1069 * * * \\
(0.0038)\end{array}$ \\
\hline Log Wage of Household Head & & & $\begin{array}{c}0.0168 * * * \\
(0.0011)\end{array}$ & & & $\begin{array}{c}0.0168 * * * \\
(0.0011)\end{array}$ \\
\hline Years of Schooling of Household Head & & & $\begin{array}{c}0.0036 * \\
(0.0021)\end{array}$ & & & $\begin{array}{l}0.0034 * \\
(0.0021)\end{array}$ \\
\hline $\begin{array}{l}\mathrm{R}^{2} \\
\mathrm{~N}\end{array}$ & $\begin{array}{l}0.0489 \\
43,681\end{array}$ & $\begin{array}{l}0.2378 \\
42,985\end{array}$ & $\begin{array}{l}0.2438 \\
42,347\end{array}$ & 43,681 & 42,985 & 42,347 \\
\hline
\end{tabular}

Notes: Standard errors clustered by cities are shown in parentheses. Asterisks denote significance levels $(*=.10, * *=.05, * * *=.01)$. The control group is individuals born between 1940 and 1954. Each column is from a separate regression which controls for city and birth year fixed effects and a rural dummy. In columns (3) and (6), we also control for whether an individual moved from East Germany after WWII. The identifying instrument for city's war destruction is city's distance to London. 
Appendix Table 2. Effect of Postwar Reconstruction on Female Labor Market Outcomes

\begin{tabular}{|c|c|c|c|c|}
\hline & Employment & $\begin{array}{c}\text { Full-time } \\
\text { Employment }\end{array}$ & $\begin{array}{c}\text { Part-time } \\
\text { Employment }\end{array}$ & $\begin{array}{c}\text { Weekly Hours } \\
\text { Worked }\end{array}$ \\
\hline & $(1)$ & $(2)$ & $(3)$ & $(4)$ \\
\hline Rubble per Cap. X Born btw.1920-1934 & $\begin{array}{c}-0.0017 * * * \\
(0.0006)\end{array}$ & $\begin{array}{c}-0.0015 * * * \\
(0.0006)\end{array}$ & $\begin{array}{c}0.0005 \\
(0.0006)\end{array}$ & $\begin{array}{c}-0.0757 * * * \\
(0.0224)\end{array}$ \\
\hline Years of Schooling & $\begin{array}{c}0.0579 * * * \\
(0.0011)\end{array}$ & $\begin{array}{c}0.0574 * * * \\
(0.0011)\end{array}$ & $\begin{array}{c}-0.0046^{* * * *} \\
(0.0014)\end{array}$ & $\begin{array}{l}0.0823 * \\
(0.0486)\end{array}$ \\
\hline Married & $\begin{array}{c}-0.2360 * * * \\
(0.0043)\end{array}$ & $\begin{array}{c}-0.2526 * * * \\
(0.0043)\end{array}$ & $\begin{array}{c}0.1339 * * * \\
(0.0036)\end{array}$ & $\begin{array}{c}-3.7657 * * * \\
(0.1395)\end{array}$ \\
\hline Number of Kids & $\begin{array}{c}-0.0714 * * * \\
(0.0022)\end{array}$ & $\begin{array}{c}-0.0742 * * * \\
(0.0022)\end{array}$ & $\begin{array}{c}0.0506 * * * \\
(0.0022)\end{array}$ & $\begin{array}{c}-0.6341 * * * \\
(0.0868)\end{array}$ \\
\hline Log Wage of Household Head & $\begin{array}{c}0.0082 * * * \\
(0.0009)\end{array}$ & $\begin{array}{c}0.0083^{* * *} \\
(0.0008)\end{array}$ & $\begin{array}{c}0.0099 * * * \\
(0.0007)\end{array}$ & $\begin{array}{c}-0.9495 * * * \\
(0.0356)\end{array}$ \\
\hline Years of Schooling of Household Head & $\begin{array}{c}-0.0319 * * * \\
(0.0010)\end{array}$ & $\begin{array}{c}-0.0313 * * * \\
(0.0010)\end{array}$ & $\begin{array}{c}0.0081 * * * \\
(0.0014)\end{array}$ & $\begin{array}{c}-0.1741 * * * \\
(0.0451)\end{array}$ \\
\hline $\begin{array}{l}\mathrm{R}^{2} \\
\mathrm{~N}\end{array}$ & $\begin{array}{c}0.1526 \\
102,699\end{array}$ & $\begin{array}{c}0.1608 \\
102,844\end{array}$ & $\begin{array}{l}0.0754 \\
52,888\end{array}$ & $\begin{array}{l}0.0756 \\
52,888\end{array}$ \\
\hline
\end{tabular}

Notes: Standard errors clustered by cities are shown in parentheses. Asterisks denote significance levels $(*=.10, * *=.05$, $* * *=.01)$. The control group is individuals born between 1935 and 1954. Each column is from a separate regression which controls for city and birth year fixed effects, a rural dummy and whether an individual moved from East Germany after WWII. 


\section{Appendix Table 3. Effect of Postwar Reconstruction on Marriage}

\begin{tabular}{|c|c|c|c|c|c|c|}
\hline & \multicolumn{3}{|c|}{ Difference-in-Difference } & \multicolumn{3}{|c|}{ Instrumental Variable } \\
\hline & $(1)$ & $(2)$ & $(4)$ & $(4)$ & $(5)$ & $(6)$ \\
\hline Rubble per (ap.X Born btw.1920-1934 & $\begin{array}{c}0.0011 * * \\
(0.0005)\end{array}$ & $\begin{array}{l}0.0012 * * \\
(0.0005)\end{array}$ & $\begin{array}{c}0.0015 * * * \\
(0.0005)\end{array}$ & $\begin{array}{l}0.0019 * \\
(0.0011)\end{array}$ & $\begin{array}{l}0.0019 * \\
(0.0011)\end{array}$ & $\begin{array}{c}0.0011 \\
(0.0010)\end{array}$ \\
\hline Years of Schooling & & $\begin{array}{c}-0.0199 * * * \\
(0.0010)\end{array}$ & $\begin{array}{c}-0.0525 * * * \\
(0.0013)\end{array}$ & & $\begin{array}{c}-0.0199 * * * \\
(0.0010)\end{array}$ & $\begin{array}{c}-0.0525 * * * \\
(0.0013)\end{array}$ \\
\hline Log Wage of Household Head & & & $\begin{array}{c}0.0254 * * * \\
(0.0007)\end{array}$ & & & $\begin{array}{c}0.0254 * * * \\
(0.0007)\end{array}$ \\
\hline Years of Schooling of Household Head & & & $\begin{array}{c}0.0405 * * * \\
(0.0010)\end{array}$ & & & $\begin{array}{c}0.0404 * * * \\
(0.0010)\end{array}$ \\
\hline $\mathrm{R}^{2}$ & 0.0486 & 0.0568 & 0.1289 & 0.0481 & 0.0563 & 0.1285 \\
\hline $\mathrm{N}$ & 90806 & 87,180 & 86,103 & 90,806 & 87,180 & 86,103 \\
\hline
\end{tabular}

Notes: Standard errors clustered by cities are shown in parentheses. Asterisks denote significance levels $(*=.10, * *=.05, * * *=.01)$ The control group is individuals born between 1940 and 1954. Each column is from a separate regression which controls for city and birth year fixed effects and a rural dummy. In columns (3) and (6), we also control for whether an individual moved from East Germany after WWII. The identifying instrument for city's war destruction is city's distance to London. 